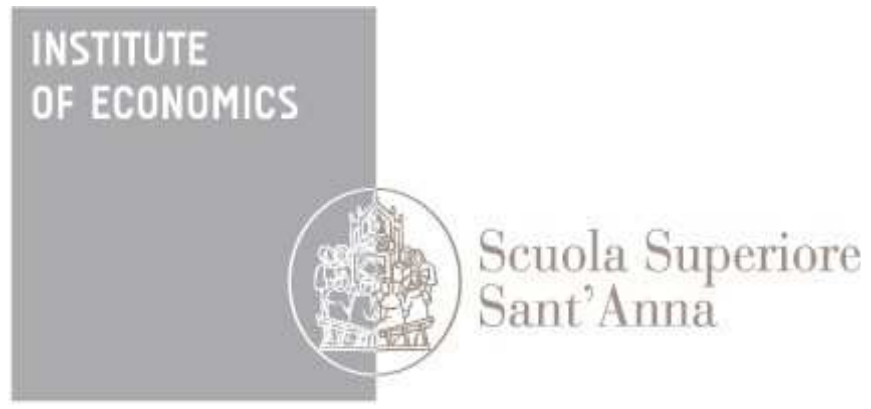

LEM | Laboratory of Economics and Management

Institute of Economics

Scuola Superiore Sant'Anna

Piazza Martiri della Libertà, 33 - 56127 Pisa, Italy ph. +3905088.33 .43$

institute.economics@sssup.it

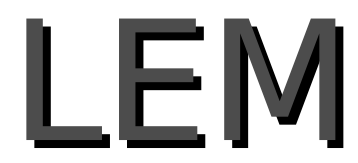

Working Paper Series

\title{
The dynamics of profits and wages: Technology, offshoring and demand
}

Francesco Bogliacino ${ }^{\circ}$

Valeria Cirillo *

Dario Guarascio §

Universidad Nacional de Colombia, Bogota', Colombia

* Institute of Economics, Scuola Superiore Sant'Anna, Pisa, Italy

$\S$ Istituto Nazionale per l'Analisi delle Politiche Pubbliche (INAPP), Rome, Italy 


\title{
The dynamics of profits and wages:
}

\section{Technology, offshoring and demand*}

[This paper is forthcoming in Industry and Innovation,

doi: 10.1080/13662716.2017.1349651]

Francesco Bogliacino

Corresponding author: Universidad Nacional de Colombia

fbogliacino@unal.edu.co

Dario Guarascio

Istituto Nazionale per l'Analisi delle Politiche Pubbliche (INAPP) - Roma

d.guarascio@inapp.org

Valeria Cirillo

Scuola Superiore Sant'Anna, Istituto di Economia, Pisa

v.cirillo@sssup.it

\begin{abstract}
This article explores the impact of innovation, offshoring and demand on profits and wage dynamics. Empirical analysis is performed on a panel of 37 industries (1995-2010) across five European countries. Our identification strategy relies on instrumental variables and recently proposed heteroskedasticity-based instruments (Lewbel, 2012). Additionally, we perform sensitivity analysis to account for omitted variables bias following the recent theoretical results of Oster (2015). The main results of our study can be summed up in three points. First, it highlights the contrasting effects of $\mathrm{R} \& \mathrm{D}$ and offshoring as wage determinants. Second, it shows that external demand is a key variable driving profits growth. Third, the categorization of workers according to skill level shows that high-skilled workers are favored by both innovation and offshoring, offshoring exerts downward pressure primarily on low-skilled wages and profits are positively correlated with high-skill wages, negatively correlated with medium-skill wages and not correlated with lowskill wages.
\end{abstract}

Keywords: rent; surplus; distribution; inequality; skills; offshoring; R\&D

JEL Classification: O33, F15, J31

\footnotetext{
* This paper is produced as part of ISIGrowth project on Innovation- fuelled, Sustainable, Inclusive Growth that has received funding from the European Union's Horizon 2020 research and innovation programme under grant agreement No. 649186 - ISI- Growth. A previous version of this paper circulated under the title "Where Does the Surplus Go? Disentangling the Capital-Labor Distributive Conflict". We thank participants to seminars in Rome "La Sapienza", WIID in Vienna and to the VPDE-BRICK WORKSHOP in Turin. A special thanks to Michael Landesmann and Annamaria Simonazzi for discussion of specific points of the paper. We appreciate the comments by two anonymous referees. We thank Joseph Wager for the revision of the manuscript. The opinions expressed by Dario Guarascio are his own and do not reflect in any way the position of INAPP. The usual disclaimer applies.
} 


\section{Introduction}

In this article, we identify the impact of demand, innovation and the international fragmentation of production (offshoring) on capital and labor remuneration. Moreover, we discuss their possible heterogeneous impact with respect to different skill levels. Within our theoretical framework, wage setting is affected by total employment, capital installed and total production, as we see in a standard labor-demand framework; however, our framework is enhanced by the inclusion of the international organization of production and technical change. Once bargained, wage represents a constraint on capital, and the market realization of profits depends on various sources of demand, as in a standard Kaleckian and post-Keynesian framework (Kalecki, 1939; Arestis, 1996, although classical arguments à la Ricardo, 1815 and Marx, 1867 should not be disregarded).

Although personal distribution (i.e., across households) of income is mainly explained by earnings distribution, the rise in inequality witnessed since the 1980s has been increasingly affected by functional distribution (i.e., across factors of production) of income (OECD, 2008; 2011; Bogliacino and Maestri, 2014; Piketty, 2014). As a result, the empirical evidence we provide helps understand the recent evolution of inequality in OECD countries.

This article includes a number of novel contributions. One of this paper's original insights lies in its isolation of the effect of technical change and offshoring on the bargaining between capital and labor. This is one of the very first attempts to do so, together with Foster-McGregor et al. (2016); however, these authors focus on labor demand rather than wages. Another important contribution is the estimation of the impact of various sources of demand on profits growth.

A further novelty is the analysis of the relative impact of offshoring and innovation on workers with different skill endowments.

We also contribute to the existing literature on industrial structure by expanding the rent-sharing theory proposed by Van Reenen (1996) and introducing additional elements of complexity-i.e., the interaction between R\&D activities and offshoring and the role of demand. This point is particularly important, for industry-level studies are often criticized for lacking a proper theoretical base.

Finally, we expand on the analysis proposed in Pianta and Tancioni (2008) regarding the distributional conflict between profits and wages. We depart from these authors by looking for more robust sources of identification and implementing novel techniques (Lewbel, 2012 and Oster, 2015). Moreover, Pianta and Tancioni's (2008) analysis is limited to data up to 2000 and takes into account a smaller number of sectors than our analysis, and their specification neither includes offshoring nor distinguishes by skill endowment.

Our empirical strategy relies on standard instrumental variables and the recently proposed heteroskedasticity-based instrumental variables approach (Lewbel, 2012). Identification is achieved with the use of regressors not correlated with the product of heteroskedastic errors. With 
this approach, atheoretical instruments can be generated and proper statistical tests can be provided for both the heteroskedasticity requirement and the overidentifying restrictions.

We apply our framework to industry-level data for five European countries (Germany, France, Italy, Spain and the United Kingdom) over the period 1995-2010. Our database merges data from the Community Innovation Survey, OECD STAN (STructural ANalysis) and WIOD (World Input Output Database), allowing for the measurement of different sources of demand, technology and offshoring.

We address the issue of omitted variables by means of recent methods of sensitivity analysis (Oster, 2015). Given certain assumptions regarding the relative role of observable and unobservable variables, this technique allows us to estimate the robustness of the computed effect of problems arising from omitted variables.

Our main results are as follows. We find a positive and negative effect exerted on wages by R\&D and offshoring, respectively. Exports and, to a lesser extent, internal demand are key variables for the realization of profits. When we look at the heterogeneity of effects, specifically with regard to the structure of workers' skills structure, three main stylized facts must be broached. Firstly, R\&D-driven innovation affects high- and medium-skilled wages but not low-skilled ones. Secondly, high-skilled wages have experienced more growth in "offshoring intensive" industries, whereas medium- and low-skilled wages tend to decrease in the same sectors. Indeed, this finding supports the hypothesis of offshoring's "threat effect" on low-skilled workers' bargaining power but not that of medium-skilled workers, which clashes with the main prediction made in skillbiased technical change (SBTC) and routine biased technical change (RBTC) literature (Acemoglu and Autor, 2011). Thirdly, the basic macroconflict between capital and labor does not preclude a difference in bargaining across skills: high-skilled wages tend to move as profits do, whereas medium- and low-skilled wages tend to move in the opposite direction of profits.

The article proceeds as follows: Section 2 presents the state of the art, Section 3 provides the theoretical framework, Section 4 describes the database and methodology, Section 5 illustrates the results and Section 6 offers conclusion.

\section{Related Literature}

Our approach departs from existing explanations of the change of inequality over the last three decades. The most common hypotheses have focused almost exclusively on the labor market, thereby suggesting that either trade or technical change have driven the growing earnings dispersion. Trade-related explanations stress the role played by China or other unskilled laborabundant countries, whose entrance into the global economy affects the skill premium in developed countries through comparative advantages. For their part, technical-change arguments propose an SBTC hypothesis; that is, they propose complementarity between technology and 
skills based on new innovations. ${ }^{1}$ More recent models explain the change in the wage premium through different reallocation of skills over the set of tasks directly targeted by technical change (Acemoglu and Autor, 2011; Goos et al. 2014). In these models, the wage premium is indirectly determined by the task-related innovations (routine-biased technical change) via the comparative advantage of skills with respect to different tasks.

On the contrary, we claim here that the conflict between labor and capital must be taken into account. Firstly, given that capital income is more unequally distributed than labor, a reduction of the labor share increases total inequality, and the increase in capital share has been remarkable in most OECD countries (Arpaia et al., 2009; Checchi and Garcia-Penalosa, 2010; Jorgenson and Timmer, 2011; Stockhammer; 2013; Schlenker and Schmid, 2013; Van der Hoeven, 2014; International Labour Organization, 2015). The impact of capital share on household income distribution may actually be underestimated for two reasons: On one hand, most profits go to the top one percent and standard measures, such as the Gini, are not very sensitive to changes in the tails (Atkinson et al. 2011; Bogliacino and Maestri, 2014); on the other, performance-related payments to managers (i.e., the salary of the so-called working rich) are not considered profits in many countries, though they should be (Stiglitz, 2012).

Secondly, profits are the main driver of accumulation in a capitalist economy over the long run. As a result, labor-market decisions and choice of technique are obviously related to both capital and labor. As Howell (1999) and Atkinson (1999) contend, distributive arrangements are possible options of a range determined by demand and supply, social norms and policy constraints in which rents are continuously created and shared.

Our article is directly related to structural analyses that use industry-level data. Every unit of analysis (whether micro, meso or macro) has its own pros and cons, e.g., firm-level data systematically account for heterogeneity, yet usually fail to meet external validity. In a series of recent papers (Lucchese and Pianta, 2012; Bogliacino and Pianta, 2013a; 2013b; Guarascio et al., 2014 and 2015), the methodological choice of sectoral data is premised on two principal arguments: i) demand is not a constraint at the firm level, for which business stealing allows firms to grow at the expense of their competitors, but it is downward sloping at the industry level; ii) technological trajectories are only partly captured at the microlevel using proxies of technical change, while industry-level variables internalize, to some extent, the knowledge base and

\footnotetext{
${ }^{1}$ The evidence suggests that the skill premium increased in both developed and developing countries (Acemoglu, 2002; Acemoglu and Autor, 2011). Moreover, most of the inequality increase has been within sector, which contradicts the hypothesis holding that comparative advantages (reflected in changes between sectors) are the main driver (Bogliacino and Maestri, 2014). In fact, this latter stylized fact_was taken to uphold the view that technical change should be considered primarily responsible for the increase in inequality. Empirical estimates simultaneously accounting for trade and SBTC confirm this finding (Morrison Paul and Siegel, 2001).
} 
spillovers (i.e., the network of actors and flows constituting a sectoral system of innovation, Dosi, 1988; Malerba, 2004).

Furthermore, our article directly contributes to the literature on determinants of the functional distribution of income (e.g., Pianta and Tancioni, 2008; Basu and Vasudevan, 2013). Pianta and Tancioni (2008) analyze the effect of technical change by distinguishing product and process innovation, showing that profits are driven by the "Schumpeterian" effects of new products. Wages, however, tend to be pushed upwards by new products in highly innovative sectors, whereas process innovation drives them downwards in low-tech industries. In the post-Keynesian literature, the emphasis has been essentially captured by the decline in wage share documented in OECD countries (-11.4\% as a share of GDP from the 1980s to 2007). Stockhammer (2013) analyzes this change, claiming that the most meaningful determinants are technological change, offshoring, the increasing importance of financial activities in the economy, globalization and reforms aimed at reducing the size and scale of the welfare state.

We add to the literature on innovation's effect on wages. In modern economic theory, the idea that technical change is not neutral can be likely ascribed to Hicks (1932) -although the laborsaving bias in favor of machines was clearly present in Marx and Ricardo - suggesting that laborsaving innovation is driven by falling prices of capital. Hicks's study has engendered a notable discussion of the possibility of an a priori discrimination of technology bias (Salter, 1960) or the technical conditions in terms of elasticity of substitution among factors necessary to determine an induced bias (Fellner, 1961; Kennedy, 1964; Samuelson, 1965; Von Weiszacker, 1966; Drandrakis and Phelps, 1966; more recently, Zamparelli, 2011). This theoretical discussion was revived in the 1990s after originally taking place in the 1960s; this time, it formed part of the debate over the massive introduction of ICT technologies and their effects on the dynamics of wages (Berman et al., 1994). An expansive theoretical literature has emerged in response to this debate; essentially, the conclusion has been that new technologies complement skills (Acemoglu, 2002; Acemoglu and Autor, 2011). The prediction proposed by SBTC hypothesis can be considered ambiguous, unless we specify whether bias is endogenous or not. According to Acemoglu and Autor (2011), bias ought to be made endogenous to the variations of the supply of skills, for these variations alter the patterns of incentives for those inventing task-related machinery. ${ }^{2}$ Nevertheless, Bogliacino and Lucchese (2015) use the German reunification shock affecting West Germany as a natural experiment in the variation of the supply of skills, finding no evidence of induced SBTC.

Another shortcoming of the SBTC hypothesis is brought to the forefront by the OECD (2011) and Bogliacino and Maestri (2014): Institutional reforms in labor markets appear to be responsible for

\footnotetext{
${ }^{2}$ In other words, if a firm is free to invent machinery for a skill-intensive task or an unskilled intensive one, the total supply of skills will obviously affect the market for its invention, in line with classical demandpull arguments (Bogliacino and Lucchese, 2015; Acemoglu, 2002; Schmookler, 1966).
} 
most of the change in wage inequality. As we argue here, the conceptual problem related to the SBTC hypothesis is that technology per se creates rents. The way those rents are shared should depend on bargaining between labor and capital (with institutional factors certainly playing a role). We build on work by Van Reenen (1996) and Bogliacino (2014) to propose a simple model of sharing innovation-related rents.

Finally, our work contributes to the literature on offshoring's impact on wages and profits. Most of the existing evidence on the impact of offshoring is at the firm level (Crinò, 2009). However, industry-level data are particularly suitable to the study of offshoring because of input-output matrices. Moreover, such data allow for the capture of structural heterogeneity with regard to technology and demand (Bogliacino and Pianta, 2013b; Guarascio et al. 2015, 2016; Cirillo, 2016). We hold that comparing the existing evidence at the firm level with our results is particularly telling insofar as it provides further evidence of whether - and to what extent - the microevidence supports inferences at a more aggregate level.

High-skilled wages may benefit from the offshoring of the relatively labor-intensive parts of the production process because of two mechanisms: (a) via a standard comparative advantage effect; (b) via an "organizational innovation," namely the participation in the high-tech and highly valued Global Value Chains (GVCs). However, low- and medium-skilled wages are subject to potentially negative effects; that is, the threat of delocalizing production can reduce bargaining power.

The empirical literature, which has recently undergone substantial expansion, has not arrived at a consensus regarding offshoring's impact on wages. Although some articles suggest that it may cause large employment losses among low-skilled workers and increase the wage differential (Feenstra and Gordon, 1997; Feenstra and Hanson, 1996 and 1999; Amiti and Wei, 2004; Munch, 2010; Sheng and Yang, 2012), ${ }^{3}$ Antràs et al. (2006) argue that the effect of offshoring on wages is negligible. Furthermore, these authors claim that the only impact, albeit moderate, is a positive one insofar as high-skilled workers located in the offshoring countries are concerned (e.g., Falk and Koebel, 2002 for Germany). Using a multicountry model of international trade, Burstein and Vogel (2012) detect a positive relationship between offshoring and high-skilled wages and no correlation between offshoring and countries' skill endowments. Yet, Hummels et al. (2014) do not confirm these results, instead identifying negative effects stemming from the offshoring decisions of Danish firms on wages of unskilled workers. Costinot et al. (2013) conclude that the impact of offshoring on wages is strongly heterogeneous due to the different skill compositions

\footnotetext{
${ }^{3}$ Carluccio et al. (2015b) claim that the wage premium depends on the participation of international trade and collective bargaining. Workers in high-skilled occupations complement overseas production, while workers in low-skilled occupations serve as substitutes. This effect is also related to collective bargaining, and, surprisingly, wage gains to sign firm-level agreements accrue to all workers regardless of trade intensity with a $10 \%$ wage gap when compared to industry agreements. Carluccio et al (2015a) find that skill upgrading due to offshoring occurs within—and not among—industries.
} 
of industrial sectors (similar notions are proposed by Fosse and Maitra, 2012; Milberg and Winkler, 2010 and 2013; Timmer et al, 2013 and Hummels et al., 2014).

Another research track (Slaughter, 2000; Geishecker and Görg, 2008; Mion and Zhu, 2013 for Belgium; Autor and Handel, 2013 for the US) makes the case for offshoring's negative effect on the employment level and wage share of medium-skilled workers in developed economies. In this vein, Foster-McGregor et al. (2016) analyze the impact of offshoring on labor-demand elasticity for a group of 40 countries over the period 1995-2009; they find a neutral effect of offshoring on aggregate employment, although the effect was negative for low- and medium-educated workers. Additionally, combining effects on labor and wages, Harrison and McMillan (2011) demonstrate the differentiated impact of international trade and offshoring on US wages and employment across selected occupations.

Regarding skill composition, Horgos and Tajoli (2015) show that in Germany, when offshoring takes place in relatively low skill-intensive industries, there is no significant change in the skill composition, whereas in the relatively high-skill intensive industries, the high-skill labor ratio increases. Helg and Tajoli (2005) show that skilled the employment share is positively affected by the international fragmentation of production in Italy, though there is no significant pattern in Germany.

As for the literature on innovation and skills, the research on offshoring investigates whether the interaction between skills and tasks is important in shaping the wage distribution. For example, Blinder (2009) suggests that offshorability of services depends on the distinction between personally delivered services and impersonally delivered ones. Oldeski (2014) tests the model of Acemoglu and Autor using offshoring instead of technical change as independent variable. They instrument offshoring in the US using a measure of offshoring by European firms, which are not correlated with US wages. Their estimates show that the polarization of the labor market is significantly associated with offshoring. A discussion of the literature can be found in Baumgarten et al. (2013), which we use as a reference. Becker at al. (2013) show that offshoring is related to skill upgrading in the home country and confirms that offshoring targets routine tasks. Ebenstein et al. (2014) use data from the Current Population Survey to show that both the positive effect of offshoring on high-income countries and negative effects of offshoring on low-income countries are indeed concentrated in routine tasks. However, in their estimates, skills and tasks are potentially confounded. Hummels et al. (2014) report a significant interaction among skills and tasks but do not control for spillovers, assuming that the only relevant offshoring is at the firm level. Finally, Baumgarten et al. (2013) estimate a labor-demand equation for German data the following identification strategies: 1) estimation of an instrumented offshoring-task interaction, controlling for industry-specific time dummies; 2) estimation of an instrumented occupationspecific measure of offshoring that controls for cross-industry spillovers. Their results confirm that the routine content of the task decreases the wages of both low and high skills. 
Regarding offshoring and profits, Görg and Hanley (2011) estimate the impact of service offshoring on firms' profits and innovative behavior. Working with a sample of 1,929 Irish plants, the authors observe the positive effects of service offshoring on firms' profitability and innovativeness; Hijzen et al. (2010) obtain similar results based on a panel of Japanese firms.

\section{Theoretical Framework}

Our structural model is founded on two primary building blocks. In a nutshell, our approach is based on the following sequential timing: Wages are bargained before entering into production and take into account the constraints dictated by total employment, output decisions and available or expected rents (related innovation and organization of production). Profits are realized afterwards, depending, of course, on the residual surplus (in a Ricardian sense, i.e., after paying wages) and on demand level.

On the wage-determination side, we are guided by Van Reenen's hypothesis (1996) regarding "innovation rents" captured by workers (in a similar vein, see Dunne and Schmitz, 1995). Van Reenen's framework belongs to the set of models in which wages can be above the marketclearing level (e.g., Akerloff and Yellen, 1990). According to this set of models, a causal relationship can be traced between wage level and workers' on-the-job productivity. Employers are willing to pay wages above the market-clearing level to spur productivity growth; basically, worker productivity depends on the wage received, implying that a higher wage is akin to more incentive for the worker to be productive. In one of the alternative formulations (Shapiro and Stiglitz, 1984), a wage increase is shown to decrease a worker's incentive to shirk. In other words, a wage increase boosts worker productivity and lowers direct monitoring expenses. ${ }^{4}$

Innovative rents are defined in Schumpeterian terms, and they should be derived from the temporary monopoly associated with a new product (Schumpeter, 1942). Van Reenen (1996) identifies three fundamental reasons why workers have legitimate access to portions of innovation rents: i) the time lag between input, $R \& D$ activities and output of innovation; ii) the difference in the time horizon between workers and shareholders, which is shorter for the former due to the proliferation of temporary contracts ${ }^{5}$;iii) the elements of randomness in the nature of innovation.

\footnotetext{
${ }^{4}$ In this sense, the wage explanation put forth by the "shirking model" predicts that wage differentials depend on the amount of monitoring costs between different firms and industries. Higher monitoring costs lead to higher wages. Similarly, wage differentials have been shown to be related to firm size (for which monitoring costs are higher) by various researchers (Davis and Haltiwanger, 1991; Main and Reilly, 1993; Brunello and Colussi, 1998; Arai, 2003; Lallemand et al., 2005; more recently, Bottazzi and Grazzi, 2010). We should stress that the literature on efficiency wages deals with "residual" labor productivity, which does not depend on capital equipment or technology. Ceteris paribus labour productivity may depend on (greater) worker effort and performance related incentives.

5 The empirical literature has usually overlooked the heterogeneous impacts of offshoring on workers' contract type. Few authors have explicitly addressed this research question - Gorg and Gorlich (2015) and Lee and Lee (2015), among others. Most studies, however, have shown that workers hired under temporary contracts are usually paid less than those with a permanent position-Booth et al. (2002), Boeri (2011) and Khan (2007). Temporary workers are the least protected group and have the weakest bargaining power.
} 
Our theoretical specification of wage determinants follows the extension of the innovation rent hypothesis as formulated by Bogliacino (2014). We adapt this model of wage determinationoriginally meant to study the relation between technical change and firms' labor demand- to identify the simultaneous role and interplay of technical change and offshoring in shaping wage dynamics.

To model profits, we combine our wage equation with a Kaleckian profit equation. As a result, the profits equation accounts for the role of demand as well as the effect of social conflict. We determine that the impact of wage variations on profits is indirectly shaped by the contrasting effect of - and interaction of - technical change and production offshoring.

In the second part of this paper, we turn our attention to the heterogeneous impact after accounting for the classification of workers by skill.

\subsection{The Wage Equation}

The wage equation is a standard log-linear specification augmented with a term for surplus sharing. The fact that technology and organization of production affect the creation and distribution of rents means we can, in principle, use a nonlinear equation:

$$
\log \left(W_{i t}\right)=\alpha_{0}+\alpha_{1} \log \left(L_{i t}\right)+\alpha_{2} \log \left(Y_{i t}\right)+\alpha_{3} \log \left(\Phi\left(\log \left(O F F_{i t}\right), \log \left(R \& D_{i t}\right)\right)+\epsilon_{i t}\right.
$$

where subscript $\mathrm{i}$ and $\mathrm{t}$ indicate the industry-country couple and the observation time, respectively; w stands for wage, $L$ for employment, Y for total output and R\&D and OFF represent $R \& D$ and offshoring, respectively. ${ }^{6}$

The $\Phi$ function nonlinearly captures the effects of technology and organization of production. This wage equation can be viewed as an extension of Bogliacino's (2014) specification, in which the author explains the relationship between technical change and labor demand at the firm level by considering how "innovation rents" are shared. Using firm R\&D expenditures as a proxy for innovation, Bogliacino (2014) suggests a nonlinear relationship between technical change and labor demand. Such nonlinearities are determined by a scale effect-linked to the decreasing returns to scale of R\&D investments owing to fixed factors - and a size effect-linked to larger firms' ability to exploit greater benefits from research activities. As mentioned in the introduction of the present paper, the presence of such nonlinearity may be better captured at the industry level than at the microlevel because of spillover effects.

They are the first group of employees to be affected by either positive or negative shock such as offshoring (Lee and Lee, 2015).

${ }^{6}$ Furthermore, (1) can be formally derived from the first-order conditions with a Constant Elasticity of Substitution (CES) production function (Chennels and Van Reenen, 1999). 
In the present investigation, the theoretical framework is broadened to account for the organizational change associated with offshoring. Similarly, due to organizational and product innovation (related to offshoring and $\mathrm{R} \& \mathrm{D}$, respectively), rents may accrue, and these rents are bargained for in the labor market.

To identify the effects of R\&D and offshoring, we must expand the $\Phi$ function in (1) with a Taylor approximation. If we take a log formulation, we get (2):

$$
\begin{aligned}
& \log \Phi(z, y)=\log \Phi(0,0)+\frac{\Phi_{1}(0,0)}{\Phi(0,0)} x+\frac{\Phi_{2}(0,0)}{\Phi(0,0)} y+\left(-\Phi^{-2}(0,0) \Phi_{1}^{2}(0,0)+\right. \\
& \left.\Phi^{-1}(0,0) \Phi_{11}(0,0)\right) x^{2}+2\left(-\Phi^{-2}(0,0) \Phi_{1}(0,0) \Phi_{2}(0,0)+\Phi^{-1}(0,0) \Phi_{12}(0,0)\right) x y+ \\
& \left(-\Phi^{-2}(0,0) \Phi_{2}^{2}(0,0)+\Phi^{-1}(0,0) \Phi_{22}(0,0)\right) y^{2}+o\|(x, y)\|^{2}
\end{aligned}
$$

where $\mathrm{z}$ and $\mathrm{y}$ are $\mathrm{R} \& \mathrm{D}$ and offshoring variables in log terms, respectively. Now, we can express our specification of the wage at the industry level:

$$
\begin{aligned}
& \log \left(W_{i t}\right)=\alpha_{1} \log \left(L_{i t}\right)+\alpha_{2} \log \left(Y_{i t}\right)+\alpha_{3} \log \left(R \& D_{i t}\right)+\alpha_{4} \log \left(O F F_{i t}\right)+\alpha_{5} \log ^{2}\left(R \& D_{i t}\right)+ \\
& \alpha_{6} \log \left(R \& D_{i t}\right) * \log \left(O F F_{i t}\right)+\alpha_{7} \log ^{2}\left(O F F_{i t}\right)+u_{i}+e_{i t}
\end{aligned}
$$

Differentiating (3) to get rid of the fixed effects $u_{i},{ }^{7}$ we finally obtain our empirical specification of the wage equation (4):

$$
\begin{gathered}
\Delta \log \left(W_{i t}\right)=\alpha_{1} \Delta \log \left(L_{i t-1}\right)+\alpha_{2} \Delta \log \left(Y_{i t-1}\right)+\alpha_{3} \Delta \log \left(R \& D_{i t-1}\right)+\alpha_{4} \Delta \\
\log \left(O F F_{i t-1}\right)+\alpha_{5} \Delta \log ^{2}\left(R \& D_{i t-1}\right)+\alpha_{6} \Delta\left[\log \left(R \& D_{i t-1}\right) * \log \left(O F F_{i t-1}\right)\right]+\alpha_{7} \Delta \\
\log ^{2}\left(O F F_{i t}-1\right)+\Delta e_{i t}
\end{gathered}
$$

Per equation (4), wages are driven by: the level of economic activity expected by the firm; innovation $(R \& D)$; and offshoring activities, which may interact with $R \& D$ and have nonlinear effects. ${ }^{8}$

All explanatory variables used here are lagged. Theoretically, we operate from the assumption that the effects of market dynamics (proxied by the change in output and employment), innovation (proxied by $\mathrm{R} \& \mathrm{D}$ efforts) and investments (proxied by expenditure on new machinery) are observable after a one-period lag (Bogliacino and Pianta, 2013a; 2013b; Guarascio et al, 2015).

\footnotetext{
${ }^{7}$ We should mention that fixed effects also capture country-level institutional variables, which clearly affect the labor market. Moreover, by using country dummies, we control for country-specific time trends, which capture institutional evolution.

${ }^{8}$ In line with Kramarz (2008), we hypothesize that offshoring can affect wages by altering firms' threat point, thereby changing the overall rent shared by firms and workers. In other words, firms willing to reduce union strength use offshoring as an instrument of worker discipline.
} 
Empirically, the inclusion of lagged variables helps eliminate the risk of simultaneity-related endogeneity (infra, Subsection 4.2 for identification and 5.3 on robustness).

We expect firms' R\&D efforts to exert a positive effect on wage dynamics, as propounded by the "innovation rent" hypothesis (Van Reenen, 1996). If we assume that average wages are shaped by bargaining, whose asymmetry is driven by innovation and international organization of production, then offshoring variables will negatively affect wages. Note that the interaction term between $R \& D$ and offshoring activities may have varying sign and significance due to the preponderance of one of the two effects.

The main mechanisms pointing to complementarity between $R \& D$ and offshoring are related to: i) the role of organizational innovations; ii) the innovative push that the inflow of high-tech intermediates may drive; and iii) the incentive toward technological competitive strategies stemming from internationalization. Concerning the first channel, the key idea is that the reshaping of the production process implied by delocalization requires an update of firms' internal and external organization. In this respect, it may be argued that as offshoring activities become more important, firms enhance their innovative efforts to maximize the productivity gains related to such activities. Regarding the second channel, the hypothesis is that the introduction of imported high-tech intermediates may require a technological upgrade of the existing capital equipment. Such an upgrade, in turn, may lead to an increase in the R\&D efforts aimed at rapidly renewing the production structure. The third channel refers to the dominance of technological competitiveness strategies among the more internationalized firms. For example, Colantone and Crinò (2014) find that the introduction of new imported intermediates stimulates the quality and complexity of goods produced domestically. In addition, several authors emphasize the tendency toward the offshoring of R\&D activities (e.g., Lewin, Massini and Peeters, 2009). In this respect, one may argue that the more innovative and internationalized firms have, on one hand, an internationally fragmented production chain; on the other, they heavily rely on technological competitiveness strategies based on $\mathrm{R} \& \mathrm{D}$ efforts. An alternative, IT-based explanation of complementarity between technical change and offshoring is presented by Bartel et al. (2005).

Moreover, the magnitude and direction of innovation and offshoring with regard to wages may also differ according to workers' skill categories. We expect high-skilled workers to be more apt to capture higher shares of "innovation rents" relative to medium- and low-skilled workers. In the case of offshoring, we expect a similar outcome: a more conspicuous negative effect on wages for low- and medium-skilled workers.

\subsection{The Profits Equation}

As we anticipated, the profits equation is sequential with respect to wages, for actual profits depend on potential profits (surplus) and demand. In our formulation, we expand on Kalecki (1939), using input-output matrices to disaggregate different sources of demand. 
Profits are the realized surplus after sharing portions of the rents with workers.

$\Pi=p q-c q-s q$

Where $\mathrm{p}$ is the price, $\mathrm{c}$ is the unit cost (in a classical sense, e.g., reproduction costs) and the last term is the rent shared with the workers ( $\mathrm{s}$ is the unit rent accruing to workers). Based on (5), we can define the markup (m) as the difference between price and unit cost; including logarithms, we have the expression:

$\log (\Pi)=\log (m-s)+\log (q)$

To identify the first term, we need a bargaining conflict variable and a markup variable. Although we have technology and offshoring, both are related to ex-ante investment and present risk, which is why we have included them in the wage equation. Consequently, we use investment as a measure of embodied technical change to proxy for potential surplus through the installed capacity. Another variable that may influence the markup is the average firm size, which is correlated with the market concentration of industries. When market concentration is higher, we expect larger profits. As a measure of bargaining conflict, we utilize the estimated rate of change of wages given by equation (4). To capture the second term in (6), we turn to the input-output structure, identifying the different sources of demand, i.e., both internal and external. The role of external demand may be particularly relevant because in the presence of free movements of capital, internal demand is limited by the external constraint (Escaith, 2016; Newfarmer and Stzajerowska, 2012; Carlin et al. 2001). It is important to stress that the inclusion of surplus and surplus realized through demand is a key departure from standard input-demand framework.

Therefore, we can build off (6) to establish our simple empirical specification of industry profits:

$$
\begin{aligned}
& \log \left(P_{i t}\right)=\alpha_{0}+\alpha_{1} \log \left(S I Z E_{i t}\right)+\alpha_{2} \log \left(I_{i t}\right)+\alpha_{3} \log \left(C_{i t}\right)+\alpha_{4} \log \left(E X P_{i t}\right)-\alpha_{5} \log \left(W_{i t}\right)+ \\
& u_{i}+\varepsilon_{i t}
\end{aligned}
$$

where subscripts $i$ and $t$ indicate the industry-country couple and the time of the observation, respectively; w stands for wage, EXP for export, $\mathrm{C}$ for consumption demand and I for investment. Taking the first difference of (8) to remove the fixed effects $u_{i}$, we get:

$$
\begin{aligned}
& \Delta \log \left(P_{i t}\right)=\alpha_{1} \Delta \log \left(S I Z E_{i t}\right)+\alpha_{2} \Delta \log \left(I_{i t}\right)+\alpha_{3} \Delta \log \left(C_{i t}\right)+\alpha_{4} \Delta \log \left(E X P_{i t}\right)- \\
& \alpha_{5} \Delta \log \left(W_{i t}\right)+\varepsilon_{i t}
\end{aligned}
$$


where the wage is the estimated from (4). The following effects are expected: The presence of large firms - signaling a relatively low degree of competition within the sector-is positively correlated with variations in profits; expenditure on new machinery and equipment-i.e., embodied technological change - and demand (and export in particular) positively affect variations in profits; wages, on the contrary, negatively impact profits and, in so doing, capture bargaining conflict.

\section{Data and Methodology}

\subsection{The SID Database}

For this paper, we use the Sectoral Innovation Database (SID) developed at the University of Urbino (Bogliacino and Pianta, 2013a). The SID is the result of combining different data sources at the country-sector level. For innovation variables, such as R\&D expenditure, average firm size and expenditure on new machinery and equipment, data are drawn from four European Community Innovation Surveys - CIS 2 (1994-1996), CIS 3 (1998-2000), CIS 4 (2002-2004) and CIS 6 (2008-2010) — and subsequently matched to industry-level data from the WIOD Nace Rev. 1 database. To establish the requisite conditions for comparability, innovation variables taken from CIS6 have been converted into Nace Rev.1 using the conversion matrix found in Perani and Cirillo (2015). ${ }^{9}$

For production and demand variables, i.e., wages, profits, demand and total employees, we use data from WIOD. Input-output tables are employed to connect domestic and imported inputs and industries, helping disentangle the production structure (Yamano and Ahmad, 2006; Timmer et al., 2013). All data have been converted into euros and constant prices. Data are available for the two-digit NACE classification for 20 manufacturing and 17 service sectors; all data refer to the total activities of industries. ${ }^{10}$

The country coverage of the database includes five major European countries (Germany, France, Italy, Spain and the United Kingdom) that represent the majority of the European economy (71\% of the entire EU28's GDP). ${ }^{11}$ The selection of countries and sectors has been made with an eye

\footnotetext{
${ }^{9}$ We use CIS and not ANBERD or KLEMS as source for the innovation variables because we also needed the measure of embodied technical change and we preferred to have only one source for innovation variables. Nevertheless, the methodology for converting CIS firm-level data into industry-level data ensures consistency with other sectoral-level variables in the data set (Bogliacino and Pianta, 2013a), so no differences with respect to OECD-ANBERD or EU-KLEMS can be detected.

${ }^{10}$ In line with the precedent established by empirical literature on the impact of offshoring (FosterMcGregor et al., 2016; Landesmann et al., 2015), we excluded the (Nace Rev.1) sector 23 (mineral oil refining, coke \& nuclear fuel). Previous analyses performed using WIOD and SID data showed that results were quite sensitive to the inclusion of this particular sector. The sector stands out in many respects; for instance, it has a very high degree of vertical specialization, high energy intensity, extremely high labor productivities, excessive capital coefficients, etc.

${ }^{11}$ The country choice stems for the availability of data in the SID database. In particular, data on R\&D intensity and Expenditure for new machineries are not available for additional countries present in the SID (e.g., Portugal, Sweden and Norway). Therefore, we are constrained to the five countries under
} 
toward avoiding limitations in data access (on account of the low number of firms in a given sector for a given country or on account of the policies on data released by various national statistical institutes).

As for the panel's time structure, economic and demand variables are calculated for the periods 1996-2000, 2000-2003, 2003-2007 and 2007-2010. Innovation variables are taken from innovation survey (data gathered in waves): the first wave (CIS II) spans 1994-1996 and aligns with the first period of economic variables; the second wave (CIS III) spans 1998-2000 and aligns with the second period of economic variables; the third wave (CIS IV) spans 2002-2004 and aligns with the third period of economic variables; the last wave (CIS VI) spans 2006-2008 and aligns with the fourth period of economic variables. ${ }^{12}$ See Table 1 for the variables used.

Table 1. List of Variables

\begin{tabular}{lcc}
\hline Variable & Unit & Source \\
\hline In-house R\&D exp. per employee & Thousands of euros/empl. & SID - (CIS Var.) \\
New machinery exp. per employee & Thousands of euros/empl. & SID - (CIS Var.) \\
Average firm size & Number of employees & SID - (CIS Var.) \\
Rate of gr. of Exports & Annual rate of growth & SID - (WIOD I-O Var.) \\
Rate of gr. of Intermediate Demand & Annual rate of growth & SID - (WIOD I-O Var.) \\
Rate of gr. of Final Demand & Annual rate of growth & SID - (WIOD I-O Var.) \\
Rate of gr. of Offshoring (F \&H Nar.) & Simple difference & SID - (WIOD I-O Var.) \\
Rate of gr. of Wages & Annual rate of growth & SID - (WIOD I-O Var.) \\
Rate of gr. of Profits & Annual rate of growth & SID - (WIOD I-O Var.) \\
\hline
\end{tabular}

Source: Sectoral Innovation Database (Bogliacino and Pianta, 2013a). Note: The rates of growth are compound annual rate of growth computed over three- and four-year periods (1996-2000; 2000-2003; 2003-2007; 2007-2010). In the estimations, wage variation is considered both per capita and per worked hour. Wages are computed for industry aggregates and are divided by skill (high, medium and low) according to the ISCED classification.

Economic variables are deflated using the sectoral value-added deflator from the WIOD (base year: 2000), corrected for Purchasing Power Parity (using the index provided by Stapel et al. 2004). To determine the performance variable, we compute the compound annual growth rate that approximates the difference in log; to determine innovation variables, we use expenditure per

investigation. However, we argue that the set of countries we analyze represent a very large part of the European economy. Moreover, in line with a number of studies analyzing the economic impact of offshoring, we excluded the Netherlands from our analysis. This choice is aimed at avoiding biases stemming from the so-called "Rotterdam effect," which relates to the fact that trade in goods with the Netherlands is artificially inflated by those goods being dispatched from or arriving in Rotterdam despite the ultimate destination or country of origin being located elsewhere. This point has been explicitly recognized by the European Commission's studies on trade dynamics (European Commission, 2007).

${ }^{12}$ The expenditure on R\&D and new machinery per employee contains missing values for the first two waves of CIS by construction (Eurostat). However, missing values are homogeneously distributed across countries in service industries. For a discussion of this problem, see Bogliacino and Pianta (2013a). 
employee (the flow) as a proxy for the change in the stock. Wage variables are expressed as hourly wage. We rely on a narrow definition of international outsourcing that considers only imported intermediates in a given industry from the same industry (corresponding to diagonal terms of the import-use matrix). Feenstra and Hanson (1996) refer to this measure as narrow offshoring (FHN), and the authors claim FHN is the best indicator by virtue of its correspondence to the definition of offshoring as a process taking place within the industry. The formal expression of FHN is:

OFFSH $H_{i, j, t}^{F H N}=\frac{\text { Imported_Int_Inputs } s_{i, k \neq j, t}}{\text { Total_Int_Inputs }_{i, j, t}}$

where $\mathrm{i}$ stands for the industry, $\mathrm{j}$ for country and $\mathrm{t}$ for time. This indicator is highly correlated with other measures of offshoring. Of the alternative indicators, there is: the Feentsra and Hanson broad indicator, which is measured as the industry sum of non-energy intermediate imported inputs from all foreign industries by the total sum of imported and domestically produced intermediate goods; high-tech offshoring, computed as the share of intermediates inflowing from Science Based and Specialized Suppliers sectors, defined according the to the Revised Pavitt Taxonomy of Bogliacino and Pianta (2016); and low-tech offshoring, the share of intermediates inflowing from Scale Intensive and Supplier Dominated sectors (defined according to the same classification). The Pearson rho between FHN and the Feenstra and Hanson broad indicator is .83 ( $p<.0001)$; between FNH and the high-tech offshoring indicator of Guarascio et al. (2014 and 2015), it is .77 ( $p<.0001)$; between FNH and the low-tech offshoring indicator, it is .75 ( $p<.0001)$. The correlation between FNH and FNH limited to manufacturing is .76 ( $p<.0001)$. Castellani et al. (2013) question some of the most widely used offshoring indicators, suggesting that they are driven by structural change more than international fragmentation, at least with regard to business services. An overall assessment of the qualities of the offshoring indicators can be found in Horgos (2009).

To sum up, the data set is a comprehensive panel that encompasses four periods across the years 1995 to 2010 in five major European countries.

The following subsection provides descriptive evidence of the main variables and relationships studied herein. In Figure A1 (see the Appendix), we plot the average rate of change by subperiod and by country for the variables wage per hour and profit.

Table 2. Descriptive statistics

\begin{tabular}{lll}
\hline Variable & Statistics & Whole sample \\
\hline Wages $(\%)$ & Mean & 2.35 \\
\hline
\end{tabular}




\begin{tabular}{lll}
\hline & Std. Dev. & 3.18 \\
Profits (\%) & Mean & 2.51 \\
& Std. Dev. & 2.05 \\
R\&D per employee & Mean & 2.63 \\
& Std. Dev. & 4.86 \\
New mach. per employee & Mean & 1.63 \\
Narrow offshoring & Std. Dev. & 2.27 \\
& Mean & 1.74 \\
Average firm size & Std. Dev. & 0.79 \\
& Mean & 0.34 \\
\hline
\end{tabular}

Source: Compound average annual rate of variation for the entire sample (DE, IT, ES, FR and the UK, 1995-2010). Sectoral Innovation Database (Bogliacino and Pianta (2013a). Note: Wages are sectoral wages per worked hours. Profits are the sectoral aggregated gross operating surplus. R\&D expenditure and Expenditure on new machinery are expressed in thousands of euros per employee. All the variables are in euros and in real terms. Average firm size is computed dividing sector total employment by the number of firms in the sector.

Table 2 reports the main descriptive statistics for the key variables computed over the whole sample of industries.

\subsection{Econometric Strategy}

Consider the following system:

$$
\begin{aligned}
\Delta \log \left(W_{i t}\right)=\alpha_{1} & \Delta \log \left(L_{i t-1}\right)+\alpha_{2} \Delta \log \left(Y_{i t-1}\right)+\alpha_{3} \Delta \log \left(R \& D_{i t-1}\right)+\alpha_{4} \Delta \log \left(O F F_{i t-1}\right) \\
& +\alpha_{5} \Delta \log ^{2}\left(R \& D_{i t-1}\right) \\
& +\alpha_{6} \Delta\left[\log \left(R \& D_{i t-1}\right) * \log \left(O F F_{i t-1}\right)\right]+\alpha_{7} \Delta \log ^{2}\left(O F F_{i t-1}\right)+e_{i t}
\end{aligned}
$$

$$
\begin{gathered}
\Delta \log \left(P_{i t}\right)=\alpha_{1} \Delta \log \left(S I Z E_{i t}\right)+\alpha_{2} \Delta \log \left(I_{i t}\right)+\alpha_{3} \Delta \log \left(C_{i t}\right)+\alpha_{4} \Delta \log \left(E X P_{i t}\right) \\
-\alpha_{5} \Delta \log \left(W_{i t}\right)+\varepsilon_{i t}
\end{gathered}
$$

The dependent variables are: variation of total sectoral profits and change of wage per worked hours. Though a more specific investigation of rates of return on capital may be pertinent, the critiques raised with respect to the data on fixed capital assets of industries led to our concern with the possibility of admitting too much noise. Yet, working under the assumption that capital stock does not change as fast total profits at the industry level, it is reasonable to expect the variation of the latter to serve as a good proxy for capital returns. On the contrary, the wage bill 
directly depends on the number of hours worked. Therefore, to properly identify the relationship between labor remuneration, innovation and offshoring, the hourly wage is more appropriate for the present analysis (Pianta and Tancioni, 2008).

The system in (10) is triangular, for the dependent variable in the first equation - the average annual change in wages - appears on the right hand side in the second equation, which helps explain the change in profits. The identification strategy is articulated below.

To capture the effects of the covariates under OLS, strong exogeneity is required, i.e., exogeneity with respect to the random terms and absence of feedback from the unobservables to covariates. To mitigate the severity this problem, we initially calculate first differences for all variables in both rows of the system to get Equation (10). Such a step removes the time-invariant part. As spelled out in Section 3, we calculate long differences with three- to four-year lags to harmonize the differences in data structure between CIS and other data sources. Long differences of this nature allow us to soften the autoregressive character of variables; likewise, these differences are suitable for use as reliable instruments when dealing with endogeneity problems (Caroli and Van Reenen, 2001; Piva et al., 2005) because the absence of time path of the unobservables is the key identifying assumption.

From there, in accordance with first-difference specification, identification requires the regressors be orthogonal to the innovation in the random errors term and to no longer be free of feedback. This identification restriction is achieved in the wage equation by considering the first lag of the explanatory variables $-\mathrm{R} \& \mathrm{D}$ intensity, offshoring, change in employment and gross output. Econometrically, the use of covariates at their first lag is crucial given that doing so avoids any risk of endogeneity related to variable simultaneity.

Next, we establish estimates for the profits equation. Here, endogeneity is induced by the contemporaneity of demand components (and wage) to the innovation in the standard error. ${ }^{13}$ As a result, we use a double instrumental variable approach to achieve consistency in the estimation of the second equation in (10). To begin, we employ a standard IV approach, instrumenting regressors using the lag structure (more precisely, the set of instruments includes the lagged rate of change of variables, of lagged value added, country, Pavitt and time dummies). Then, we use the novel heteroskedasticity-IV technique proposed by Lewbel (2012). The logic behind this instrumentation is the following: in standard IV techniques, the econometrician relies on an orthogonality restriction between the instrument and the endogenous independent and an exclusion restriction between the instrument and the structural model. In Lewbel's (2012) approach, the second condition is replaced by a restriction on the correlation between the

\footnotetext{
${ }^{13}$ As in the case of the technological and offshoring variables in the wage equation, the variable capturing embodied technical change in the profits equation is considered at its first lag. This choice reflects the hypothesis of the time lag needed for technology to exert its effects and, as was true for the wage equation, avoids the risks associated with simultaneity-related endogeneity.
} 
variance-covariance matrix of the error term and the original instrument. Using higher moments for identification provides less reliable estimates but offers the advantage of providing instruments in situations in which standard exclusion restrictions are not plausible.

Technically, this method provides identification in mismeasured regressor models, triangular systems and simultaneous-equation systems. Identification comes from a heteroskedastic covariance restriction that has been shown to be a feature of many endogeneity or mismeasurement models. Lewbel's technique (2012) opens the possibility of identifying structural parameters in regression models with endogenous or mismeasured regressors in the absence of traditional identifying information such as external instruments or repeated measurements. In this context, identification is achieved via regressors not correlated with the product of heteroskedastic errors, which is part of many models whose error correlations can be traced to an unobserved common factor. The greater the degree of heteroskedasticity in the error process, the higher the correlation between the generated instruments and the included endogenous variables (these are the dependent variables in the auxiliary "first stage" regressions). We can highlight two strengths to this approach: i) the identification assumption can be tested with a heteroskedasticity test (Breusch-Pagan test); ii) the availability of multiple instruments makes an overidentification test possible.

In this second step, the potential effect of omitted variables is estimated. Following Oster (2015) and Gonzales and Miguel (2015), this sensitivity analysis basically aims to infer the potential impact of omitted variable bias from the stability of the coefficients of interests when further controls are added. Based on the key (unverifiable) assumption that the selection on observables is the same as the selection on unobservables, after adjusting for differences in the variance of these distributions, we can calculate the bias and estimate the value of the coefficient after correcting for bias. The formula for this coefficient is:

$\overline{\bar{\alpha}}=\hat{\alpha}^{*}-\left(\hat{\alpha}-\hat{\alpha}^{*}\right) * \frac{R_{\max }-R^{*}}{R^{*}-R^{o}}$

where, $\hat{\alpha}^{*}$ and $R^{*}$ are, respectively, the coefficient estimate and $\mathrm{R}$ squared from the regression using observable covariates, and $\hat{\alpha}$ and $R^{o}$ are, respectively, the coefficient and R squared from the uncontrolled regression. The key to understanding this procedure is the $R_{\max }$. This represents the $\mathrm{R}$ squared when y is regressed against both observable and unobservable controls, which is clearly unknowable and is a degree of freedom. In our investigation, we heed the suggestions of Gonzales and Miguel (2015) and calculate four different scenarios: (1) a conservative scenario where $R_{\max }=1$, which would be the case given zero measurement error; (2) a scenario where $R_{\max }=2 R^{*}-R^{o}$, which corresponds to the assumption that the relationship between the treatment and the observables is the same as the relationship between the treatment and the 
unobservables (Bellows and Miguel, 2009); (3) Oster's (2015) proposal of $R_{\max }=$ $\operatorname{Min}\left\{2.2 R^{*}, 1\right\}$; and (4) a rule of thumb $R_{\max }=.8$, which corresponds to a measurement error of $20 \%$.

The baseline single-equation estimations are performed using the weighted least squares (WLS) estimator. As explained in Bogliacino and Pianta (2013a), based on the discussion in Wooldridge (2002: Ch. 17) industry data are grouped data of unequal size. The contribution in terms of information is asymmetric, affecting the consistency of the estimator. We prefer the number of employees over the value added because this number is not affected by price effects.

Lastly, we investigate how the dynamics of profits and wages are reshaped across skill groups. We apply the three-stage least squares (3SLS) model because of the presence of common shocks across skill groups after splitting industry wages up into high-, medium-, and low-skilled groups (per ISCED categories). In this case, the instruments are: endogenous variable lags, lagged valueadded and a set of dummies capturing country- and industry-level heterogeneity.

\section{Results}

\subsection{Main Results}

In this section, we present the results of the empirical analysis conducted on our panel of European industries.

As explained in the previous section, we proceed sequentially. Table 5 contains the wage-equation estimation, and Table 6 reports the profits-equation estimation. All estimations have been performed with White-Huber heteroskedasticity robust standard errors. ${ }^{14}$

The results in Table 5 underscore the importance of innovation - proxied here by R\&D effortsand offshoring as drivers of industry wage dynamics. Innovation has a positive and concave effect on wage. As expected, offshoring exerts downward pressure on wages. The coefficient related to the narrow offshoring index (calculated for the initial year with respect to the dependent variable period of variation) is negative in sign. The effect of offshoring on wages is approximately linear, for the squared term is not significant.

The evidence is inconclusive on whether there is an interaction or not: The sign is negative but not significant $(\mathrm{t}=-1.02, \mathrm{p}=.30)$. The negative sign could be interpreted as a differential impact of innovation on those industries for which offshoring is carried out, or, alternatively, as a reflection of the fact that in presence of offshoring, workers reap less benefits from innovative rents.

Turning our focus to the wage equation's other variables, in the WLS model, lagged change in employment and gross output have coefficients that are not significant.

\footnotetext{
${ }^{14}$ For the profits equation, the Breusch-Pagan statistic is Chi2 $(1)=77.43(p<.01)$; for the wage equation, it is chi2(1)=31.04 ( $\mathrm{p}<.01)$. We used a diagnostic test to check multicollinearity; results show this concern can be ignored, for the variance inflation factor is 1.04 for the profits equation and 3.43 for the wage equation.
} 
Profits-equation results estimated with the WLS, IV and the heteroskedasticity-IV estimator (Lewbel, 2012) can be found in Table 6. The negative impact of wages on profits is strong and significant across estimations. The WLS estimation (first column-Table 6) shows that both domestic demand and exports are positive drivers of profits growth. Nevertheless, such results may be biased by various sources of endogeneity, such as omitted variables or simultaneity of wage, demand components and unobservables.

Therefore, Columns (2) and (3) represent our benchmark; in these columns, we utilize instrumental variables. The use of instruments leads to a partial confirmation of the results obtained with the WLS. For instance, an increase in wages continues to negatively impact profits. Looking at demand variables, in both the IV and the heteroskedasticity-IV specifications, domestic demand loses significance while exports turn out to be the strongest profits driver. Together, these results fit with previous findings by Bogliacino and Pianta (2013a). Surprisingly, it seems that no role in explaining profits can be attributed to lagged investments (proxied by expenditure on new machinery and related to the embodied technical-change hypothesis) or firm size (which proxies the degree of market competitiveness).

The validity of the proposed instruments is not rejected: in Column (2), we run the Sargan-Hansen test, which does not reject the null of overidentifying restrictions ( $p=.29)$. In column (3), we report the heteroskedasticity test validating the added instruments ${ }^{15}$ and the overidentification test, which does not reject the null of absence of correlation between the overidentifying instruments and standard errors $(\mathrm{p}=.23)$.

The presence of misspecification is rejected by means of a Ramsey test $(F(3,384)=1.59 ; p=.19)$. In Table A3 (of the Appendix), the baseline equation is performed with the share of managers as an additional level of control — doing so proxies managerial ability, which is likely to affect profits dynamics. No significant changes are observed.

Finally, we run a sensitivity analysis on the inclusion of contemporaneous variables in the profits equation as proposed by Oster (2015). These results are presented in Table A4 (of the Appendix) using different values of $R_{\max }$ - the maximum $R$ squared in an ideal regression of outcome over observables and unobservables. Additionally, the table contains an estimation of the coefficient after correcting for bias. We are primarily interested in determining whether the interval composed by the estimated coefficient and the coefficient corrected for omitted variable bias is

\footnotetext{
${ }^{15}$ In Lewbel's (2012) framework, the greater the degree of scale heteroskedasticity in the error process, the higher the correlation between the generated instruments and the included endogenous variables, which are the regressors in auxiliary regressions. To ensure the reliability of the adopted procedure, we perform the auxiliary regressions - compound rate of change of demand and exports against all instrumentsseparately, thus testing for the presence of heteroskedasticity. The results of the Breusch-Pagan test (Table 6) reinforce the validity of the strategy employed here. As in Millimet and Roy (2015), land prices, market proximity, total road mileage and their respectively lagged values are used to build instruments in the specification of foreign direct investment relative to trade volumes; we used the lagged values of changes in domestic demand, export and value added to generate instruments in a circumstance of measurement error or omitted variables, as in the case of our profit equation.
} 
bounded away from zero. The estimated coefficients are consistent with the expected effects in the case of wage and export, i.e., the negative coefficient for the former supports the existence of bargaining conflict, and the positive coefficient for the latter is consistent with the hypothesis that profits are realized through exports. ${ }^{16}$

${ }^{16}$ Running the two equations as a system with 3SLS further supports these results. We do not report them in the manuscript for lack of space, but they can be found in the companion working paper. 


\section{Table 5. The wages equation}

Dependent Variable: Compound average rate of change of wages per worked hour.

WLS with White-Huber robust standard errors and weighted data (weights are the numbers of employee in the sector). Robust standard errors in brackets: ${ }^{*} \mathrm{p}<.10,{ }^{* *} \mathrm{p}<.05,{ }^{* * *} \mathrm{p}<.01$.

\begin{tabular}{ll}
\hline & (1) \\
& WLS \\
\hline R\&D expenditure (first lag) & 0.38 \\
& {$[0.07]^{* * *}$} \\
R\&D expenditure squared (first lag) & -0.01 \\
& {$[0.00]^{* * *}$} \\
Offshoring (first lag) & -0.26 \\
& {$[0.14]^{*}$} \\
Offshoring squared (first lag) & 3.35 \\
& {$[2.84]$} \\
R\&D*Offshoring (first lag) & -0.02 \\
& {$[0.01]$} \\
$\Delta$ Employment (first lag) & 0.02 \\
& {$[0.03]$} \\
$\Delta$ Gross Output (first lag) & 0.05 \\
& {$[0.03]$} \\
Country, Pavitt and time dummies & Yes \\
Observations & 413 \\
R2 (Adj) & \\
\hline
\end{tabular}


Table 6. The profits equation

Dependent Variable: Compound average rate of change of total sectoral gross operating surplus.

WLS with White-Huber robust standard errors and weighted data (weights are the numbers of employee in the sector), IV (endogenous regressors: compound rate of change of domestic demand and compound rate of change of exports; instruments: first lag of the endogenous regressors, lagged sectoral value added, country, time and Pavitt dummies), augmented IV-OLS (endogenous regressors: compound rate of change of domestic demand and compound rate of change of exports; instruments: first lag of the endogenous regressors, lagged sectoral value added, country, time, Pavitt dummies and generated instruments). The Sargan overidentification test refers to augmented IV-OLS estimation. Standard. errors in brackets: ${ }^{*} \mathrm{p}<.10,{ }^{* *} \mathrm{p}<.05,{ }^{* * *} \mathrm{p}<.01$.

\begin{tabular}{|c|c|c|c|}
\hline & $\begin{array}{l}\text { (1) } \\
\text { WLS model }\end{array}$ & $\begin{array}{l}\text { (2) } \\
\text { IV }\end{array}$ & $\begin{array}{l}\text { (3) } \\
\text { Heteroskedastici } \\
\text { ty-IV }\end{array}$ \\
\hline$\Delta$ Wages/worked hour & $\begin{array}{l}-1.25 \\
{[1.99]^{* * *}}\end{array}$ & $\begin{array}{l}-1.60 \\
{[0.32]^{* * *}}\end{array}$ & $\begin{array}{l}-1.52 \\
{[0.26]^{* * *}}\end{array}$ \\
\hline Average firm size & $\begin{array}{l}-0.25 \\
{[0.40]}\end{array}$ & $\begin{array}{l}-0.34 \\
{[0.65]}\end{array}$ & $\begin{array}{l}-0.43 \\
{[0.44]}\end{array}$ \\
\hline New mach. per employee (first lag) & $\begin{array}{l}0.62 \\
{[0.43]}\end{array}$ & $\begin{array}{l}-0.08 \\
{[0.56]}\end{array}$ & $\begin{array}{l}0.04 \\
{[0.55]}\end{array}$ \\
\hline$\Delta$ Domestic demand & $\begin{array}{l}0.26 \\
{[0.10]^{* * *}}\end{array}$ & $\begin{array}{l}0.53 \\
{[0.35]}\end{array}$ & $\begin{array}{l}0.11 \\
{[0.15]}\end{array}$ \\
\hline$\Delta$ Exports & $\begin{array}{l}0.12 \\
{[0.06]^{* *}}\end{array}$ & $\begin{array}{l}1.12 \\
{[0.32]^{* * *}}\end{array}$ & $\begin{array}{l}0.40 \\
{[0.15]^{* * *}}\end{array}$ \\
\hline Country, Pavitt and time dummies & Yes & & \\
\hline Observations & 393 & 390 & 390 \\
\hline R2 (Adj) & 0.18 & & \\
\hline Root Mean Square Error & & 27.05 & 23.84 \\
\hline Sargan overidentification test & & $\begin{array}{l}\text { Chi2(1) }=10.79 \\
(p=0.29)\end{array}$ & $\begin{array}{l}\text { Chi2(1)=9.20 } \\
(p=0.23)\end{array}$ \\
\hline $\begin{array}{l}\text { Breusch-Pagan test on the first stage } \\
\text { regression (Domestic demand) }\end{array}$ & & & $\begin{array}{l}\text { Chi2(1)=25.21 } \\
(\mathrm{p}<.01)\end{array}$ \\
\hline $\begin{array}{l}\text { Breusch-Pagan test on the first stage } \\
\text { regression (Exports) }\end{array}$ & & & $\begin{array}{l}\text { Chi2(1)=58.57 } \\
(p<.01)\end{array}$ \\
\hline
\end{tabular}

In the following subsection, 5.2, the heterogeneity of the impact of technology and offshoring across skill groups is investigated by means of a structural 3SLS estimation, with wages categorized in accordance with ISCED classification. 


\subsection{Impact Heterogeneity: Skills}

In this subsection, we use 3SLS to estimate a simultaneous system with the rate of change of profits along with the change of wages divided into skill categories (high, medium and low skills). Wage equations are regressed against the same covariates as in the pooled model reported in the previous section, except for the employment variable (for which we use the level of employment for each skill). In light of the difficulty of excluding the effects of common shocks across different wages, we use 3SLS.

The reason for using this four-equation system reveals our aim to unpack the heterogeneous impact on profits that a change in high-, medium- and low-skilled wages may have, as well as to identify possible heterogeneity in the impact of technology and offshoring across skills. ${ }^{17}$ Here, the identification strategy mimics the one defined in the general model.

Categorizing wages according to worker skills produces a number of relevant findings. Highskilled wages (first column of Table 7) incorporate innovation rents captured through lagged R\&D expenditure, but, in this case, the effect seems to be linear. On the contrary, the narrow offshoring indicator is reversed in sign, though also statistically significant when compared to the pooled model. Such results demonstrate, as previously argued, that high-skilled workers benefit from offshoring dynamics (as opposed to being penalized by said dynamics). As has been asserted in Fosse and Maitra (2012) and Hummels et al. (2014) outsourcing more labor-intensive parts of the production process, normally characterized by a greater reliance on low-skilled workers, could increase the demand for high-skilled jobs premised on keeping knowledge-intensive production in house. The squared value of the narrow offshoring indicator and the interaction term are not significant. The lagged change in employment and gross output are consistent with the pooled 3SLS estimates.

For medium-skilled wages (second column of Table 7), innovation has a positive impact and is characterized by an inverted U-shape relationship (also observed for the baseline estimation). Interestingly, offshoring's impact is not negative, which refutes the findings of Foster-McGregor et al.'s (2016) analysis of medium-skilled employment growth. As in the case of high-skilled wages, the coefficients associated with the lagged change in employment and gross output match those obtained when using the pooled estimation.

\footnotetext{
${ }^{17}$ Another important source of heterogeneity may be the difference between manufacturing and services. In manufacturing, $R \& D$ intensity has a positive $(t=4, p<.000)$ and concave $(t=-2.26, p=.024)$ impact on wages, and there is negative but not significant association with offshoring $(\mathrm{t}=-1.13, \mathrm{p}=.26)$. Regarding services, there is no significant association between $R \& D$ intensity and wages $(t=1.08, p=.28)$. On the contrary, wages seem to grow relatively more in services for which offshoring is more intense $(t=2.68$, $\mathrm{p}=.008)$. Nevertheless, the interaction term is negative and significant $(\mathrm{t}=-2.42, \mathrm{p}=.017)$. In total, the test on manufacturing and services suggests significant heterogeneity between the two clusters of industries, but the difference in statistical power may present an important concern here with respect to the interpretation of the results for the services.
} 
Of particular importance is the evidence related to low-skilled wages (third column of Table 7). Our findings indicate that low-skilled workers do not benefit from innovation-related rents, as evidenced by the R\&D coefficient's loss of significance for this wage group after producing positive and significant effects for the previous estimations. Also of note is the relation between offshoring activities and low-skilled wages: In contrast to offshoring's effect on high- and medium-skilled wages, it has a negative and statistically significant impact on low-skilled wages. This is a crucial point, for SBTC hypothesis predicts that the main impact of offshoring is on medium-skill wages (Acemoglu and Autor, 2011). Nonetheless, despite findings in the previous estimations, the interaction between R\&D efforts and offshoring is negative and significant. In other words, the rate of growth of low-skilled workers' wages is lower in industries characterized by higher intensity of offshoring, and such an effect prevails over any possible innovation-related positive impact.

Finally, wages-profits dynamics are significantly reshaped when explicitly accounting for different skill groups (column four of Table 7). The negative impact on profits still applies only to medium-skilled wages, while high-skilled wages are positively associated with profits, even if there is weak significance. For their part, low-skilled wages seem to have no effect on profit dynamics. These baseline results show that demand elements, especially exports growth, are again strong and significant profits drivers.

Table 7. The Wages-Profits 3SLS estimation (profits vs high-, medium- and low-skilled wages).

Dependent Variables: Compound annual rate of change of sectoral high-, medium- and low-skilled hourly wages; compound annual rate of change of sectoral profits. Time and country dummies included 3SLS with White-Huber robust standard errors. Endogenous regressors: compound rate of change of domestic demand and compound rate of change of exports. Excluded instruments: first lag of the endogenous regressors, lagged sectoral value added, country and Pavitt dummies. Robust standard errors in brackets. ${ }^{*} \mathrm{p}<.10,{ }^{* *} \mathrm{p}<.05,{ }^{* * *} \mathrm{p}<.01$.

\begin{tabular}{|c|c|c|c|c|}
\hline & $\begin{array}{c}\text { (High skill) } \\
\Delta \text { Wages/hour }\end{array}$ & $\begin{array}{l}\text { (Med. skill) } \\
\Delta \text { Wages/hour }\end{array}$ & $\begin{array}{l}\text { (Low skill) } \\
\Delta \text { Wages/hour }\end{array}$ & $\Delta$ Profits \\
\hline R\&D expenditure (first lag) & $\begin{array}{l}0.29 \\
{[0.14]^{*}}\end{array}$ & $\begin{array}{l}0.44 \\
{[0.12]^{* * * *}}\end{array}$ & $\begin{array}{l}0.23 \\
{[0.13]}\end{array}$ & \\
\hline R\&D expenditure squared (first & 0.00 & -0.01 & -0.00 & \\
\hline lag) & {$[0.00]$} & {$[0.00]^{*}$} & {$[0.00]$} & \\
\hline Offshoring (first lag) & $\begin{array}{l}0.70 \\
{[0.28]^{* * *}}\end{array}$ & $\begin{array}{l}0.18 \\
{[0.23]}\end{array}$ & $\begin{array}{l}-0.55 \\
{[0.26]^{* *}}\end{array}$ & \\
\hline Offshoring squared (first lag) & $\begin{array}{l}-6.32 \\
{[5.51]}\end{array}$ & $\begin{array}{l}-4.19 \\
{[4.61]}\end{array}$ & $\begin{array}{l}6.8 \\
{[4.99]}\end{array}$ & \\
\hline R\&D*Offshoring (first lag) & $\begin{array}{l}-0.02 \\
{[0.03]}\end{array}$ & $\begin{array}{l}-0.03 \\
{[0.02]}\end{array}$ & $\begin{array}{l}-0.07 \\
{[0.03]^{* *}}\end{array}$ & \\
\hline$\Delta$ Employment (high skilled) & $\begin{array}{l}-0.05 \\
{[0.02]^{* *}}\end{array}$ & & & \\
\hline$\Delta$ Employment (medium skilled) & & $\begin{array}{l}-0.05 \\
{[0.01]^{* * *}}\end{array}$ & & \\
\hline$\Delta$ Employment (low skilled) & & & $\begin{array}{l}-0.14 \\
{[0.01]^{* * *}}\end{array}$ & \\
\hline
\end{tabular}




\begin{tabular}{|c|c|c|c|c|}
\hline$\Delta$ Gross Output (Rate of Growth) & $\begin{array}{l}0.10 \\
{[0.05]^{*}}\end{array}$ & $\begin{array}{l}0.13 \\
{[0.04]^{* * *}}\end{array}$ & $\begin{array}{l}0.39 \\
{[0.04]^{* * *}}\end{array}$ & \\
\hline$\Delta$ Wages/hour (high skill) & & & & $\begin{array}{l}1.66 \\
{[0.48]^{*}}\end{array}$ \\
\hline$\Delta$ Wages/hour (med skill) & & & & $\begin{array}{l}-4.03 \\
{[1.15]^{* * *}}\end{array}$ \\
\hline$\Delta$ Wages/hour (low skill) & & & & $\begin{array}{l}0.65 \\
{[0.90]}\end{array}$ \\
\hline New mach. per employee (first & & & & 0.03 \\
\hline$\Delta$ Exports (instrumented) & & & & $\begin{array}{l}1.21 \\
{[0.30]^{* * *}}\end{array}$ \\
\hline$\Delta$ Dom. demand (instrumented) & & & & $\begin{array}{l}0.68 \\
{[0.29]^{* *}}\end{array}$ \\
\hline Time dummies & Yes $^{* * * *}$ & Yes $^{* * *}$ & Yes $^{* * * *}$ & Yes $^{* * * *}$ \\
\hline Obs & 385 & 385 & 385 & 385 \\
\hline Chi2 & 31.01 & 69.67 & 215.5 & 0.36 \\
\hline Root Mean Square Error & 5.41 & 4.54 & 4.87 & 29.2 \\
\hline
\end{tabular}

\subsection{Robustness of the Results}

It is important to discuss to what extent we aim to identify a causal relationship in this framework. Starting with the wage equation, our main identifying assumption is the lack of temporal dynamics in potentially omitted variables (Bellemare et al. 2015; Reed, 2015), which is implicit in the use of lags. In fact, if unobservables at time t- 1 are causally associated with unobservables at time $t$, and in presence of selection on unobservables, we may incur into biased estimates. However, this issue only emerge in terms of within-country/across-industry differential trend of unobservables because of the use of country dummies in the estimations. In fact, we remind readers that the use of the differencing operator eliminates any potential time-invariant heterogeneity.

We have two main concerns here. The first is the lack of capital stock in the wage equation. It is possible, in principle, that sectors for which the capital stock increases, thereby raising the productivity of workers and their wages, may self-select out of the offshoring strategy. If this is the case, then we should observe systematically higher wages in the presence of low offshoring. However, this potential confound is not particularly salient because of the use of Pavitt dummies after differencing, which controls for differential technological trajectories and capturing the use of different inputs (Bogliacino and Pianta, 2016). To ensure that we could safely disregard this point, we run the estimation in Column 1 of Table A2 (of the Appendix) with the composition of the employment (which is correlated with the installed capital stock). We use the share of workers with secondary and tertiary degrees (ISCED classification), but the results do not change.

Capital stock is even less of an issue for R\&D. We should expect that where capital—embodying new productivity gains - increases, there are less incentives to invest in R\&D; thus, we should 
observe an association between low R\&D and high wages. This mechanism runs counter to our hypothesis; thus, a fortiori, it strengthens our empirical evidence.

Second, it is possible that the task composition across industries affects the bargaining power of workers, for, as the literature review points out, workers assigned to routine tasks are less shielded from offshoring strategies. Again, we do not consider this to be a major issue. Our argument is threefold. Theoretically, the pattern of comparative advantage and not the subsequent reallocation determines which wages grow or not (Acemoglu and Autor, 2011), but we control for the initial pattern of comparative advantage through differencing. Empirically, if routinization drives offshoring at time t-1 (the assumption behind potential critiques), we should observe a change in the set of in-house task at time t (less routine tasks) by the very definition of offshoring, and consequently less offshoring at time $t$, with consequently higher wages associated with $\mathrm{t}-1$ offshoring. However, when we control for the occupational structure in Column 2 of Table A2 (of the Appendix) - in which we include the shares of managers and qualified personnel, classified according to ISCO-we see that effect size changes very little (although some significance is lost, $\mathrm{t}=-1.62, \mathrm{p}=.107)$. Finally, given that most of the literature on tasks is actually focused on relative wages, it could be argued that differential patterns of comparative advantages make it less likely, in general, that we can identify absolute effects on wages, which is a further a fortiori argument for the relevance of our results.

In terms of innovation, task composition across skills is not very problematic for our results because $\mathrm{R} \& \mathrm{D}$ is mainly related to product and not process innovation, as confirmed by microeconometric studies using data from various sources (Conte and Vivarelli 2005; Parisi et al. 2006). In fact, Cincera (2005) shows that $R \& D$ expenditures are explicitly oriented toward product innovation in three out of four cases.

One additional remark pertains to how to interpret the coefficient in the R\&D case. Following the logic of the model, it should be innovation output and not input that which drives wage growth, per the very definition of innovative rent. Of course, at the firm level, one may argue that high levels of unsuccessful R\&D expenditure may generate pressure to cut other costs, e.g., labor cost, but, at the industry level, this effect is essentially negligible. Nevertheless, the fact that we estimate the impact of $R \& D$ and not innovation means that we are actually underestimating the impact of this variable on the surplus: Our coefficient could be read as a sort of intention to treat; thus, it should be divided by the elasticity of the innovative production function, which the literature identifies as less than one (Denicoló, 2007). In Table A1, we report some robustness checks with the use of variables from CIS: QINNOV (share of innovative firms within the sector), QINPDT (share of product innovators), QEMAR (share of firms introducing products new to both the firm and the market) and QSENT (share of firms introducing innovation relying on internal resources). These variables are measured as share of firms and, as a result, measure innovativeness 
in relative terms; they cannot be interpreted structurally, but they at least confirm the robustness of the result.

In the profits equation, we use two different strategies. The first is the use of lagged instruments, which are based on the same assumption discussed above. In this setup, the main concern would be the exclusion restriction on $R \& D$ and offshoring, whose effect comes only through wages. This latter assumption is obviously a key theoretical assumption. Although one could argue that both $R \& D$ and offshoring may be vehicles to expand output and opportunities at the company level, our counterargument is that running the estimation at the industry level allows us to both neglect business stealing, which is less of a concern, and control for different sources of demand. The second strategy is the use of heteroskedasticity-based instruments. Obviously, the consistency of the results across estimations is a confirmation of robustness per se. Moreover, the direct estimation of the omitted variable bias in Table A4 in the Appendix suggests that this problem is negligible.

Finally, we conclude with some thoughts on the 3SLS model for the heterogeneous impact of offshoring and innovation across skills. As for the wage equation above, the possibility that the pattern of comparative advantages across tasks changes significantly for skill groups across industries is a source of legitimate concern. Empirically, our set of fixed effects should minimize this risk. As already discussed, only a shock to the change of the set of comparative advantages, both heterogeneous within the country-specific trend and/or within the Pavitt-specific trend, may induce a bias in the estimate. Theoretically, reallocation should not change the final effect on relative wages (Acemoglu and Autor, 2011), and we control for the initial pattern through differencing.

When we estimate wages for different skill groups, there is an additional concern with respect to the case of average wage. If the offshoring strategies are dynamic, i.e., with regard to the order in which high-tech (HT) and low-tech (LT) inputs are externalized, then there could be a potential endogeneity induced by the dynamic bargaining response of workers. It is reasonable to assume that LT offshoring comes first because of learning or implementation costs. At the end of the time horizon, both HT and LT offshoring occur and both high-skilled and low-skilled workers accept lower wages, although it is likely that the former are less severely affected. As we move backwards, while the impact on low-skilled workers does not change, high-skilled workers have a strategic choice: They can lower their wages today or face the risk of being fired in expectation of firms' offshoring of their tasks. If wages grow with experience, it is reasonable that as we move backwards, the inducement to accommodate firms' request to lower wages decreases: When they seek higher wages in negotiation, either workers are not fired, gaining more today, or they are fired having to move toward other sectors but gaining experience and a higher-than-equilibrium wage tomorrow. As a result, the bias in the estimation is time dependent; if we estimate the wage equation at the beginning of the period, we may underestimate the long-run impact on high-skilled 
workers. Yet, we are mainly interested in the low- and medium-skilled groups, so this problem may be disregarded because it is more a problem of external validity and ex ante impact assessment of what will happen in the future.

Nevertheless, there may be a nested econometric problem. If we are measuring offshoring over the period in which the strategy is shifting, the instrument may be poorly correlated, and this may increase the impact of the bias. In fact, keep in mind that a standard IV estimator with one explanatory variable $(\mathrm{X})$ and one instrument $(\mathrm{Z})$ has a bias of $\operatorname{Cov}(\mathrm{Z}, \mathrm{u}) / \operatorname{Cov}(\mathrm{Z}, \mathrm{X})$, with u being the unobservable for the structural model. If the numerator is not zero, the bias increases when $\operatorname{Cov}(\mathrm{Z}, \mathrm{X})$ decreases. However, the data show that this is not the case for the period covered by our empirical exercise. In particular, Bramucci et al. (2017) use the same data, though they disentangle the offshoring by type of input, and find that offshoring is still driven by manufacturing and LT sectors, for which LT offshoring strategies are clearly dominant.

\section{Conclusions}

In this article, we identify the effect of innovation, offshoring and demand on wage and profit dynamics. We sketch a model based on two key notions: (1) wages are bargained in accordance with a company's planning decisions, and the distributive conflict arises from a surplus to share (as in the range theory of wages developed by Howell, 1999) for which both technology (R\&D) and international organization of production (offshoring) define, to some extent, the distributive arrangement by shaping the bargaining power of the parties involved; (2) profits are realized if there is enough demand (per the standard principle of effective demand), and the effect is not necessarily homogeneous across different sources of demand.

In the first place, the baseline model highlights several key relationships: the contrasting impact of offshoring - pushing wages downward-and innovation-pushing wages upward; the presence of a nonlinear effect in the R\&D-wages relation; social conflict, as captured by the negative effect of wages growth on profits (see also Pianta and Tancioni, 2008); the fundamental role of demand, particularly exports, as a profits driver (Bogliacino and Pianta, 2013a).

In the second place, this article contributes to the empirical literature on offshoring's impact on wages classified according to workers' skills (e.g., Feenstra and Hanson 1996, 1999; Grossman and Rossi-Hansberg 2007, 2008 and Hummels et al., 2014).

By distinguishing three types of workers (high-, medium- and low-skilled workers), we arrived at a number of important findings: a) consistent with the rent-sharing hypothesis formulated above, innovation spurs high- and medium-skilled wages, yet it is not correlated with low-skilled ones; b) high-skilled wages are found in relatively higher "offshoring intensive" industries, for they seem to benefit from the improved efficiency likely associated with production offshoring, while low-skilled wages tend to decrease in the same sectors, which points to the prevalence of a "threat effect" that hinders low-skilled worker's bargaining power (though this does not speak to 
the situation of medium-skilled wages - see the SBTC literature for more information); c) the interaction between $R \& D$ efforts and offshoring, which is not significant in all other specifications, has a negative and significant impact on low-skilled wages, confirming the downward pressure exerted by offshoring on these wages; d) the wages-profits relationship undergoes far-reaching changes when skills are taken into account - that is, high-skilled wages are correlated with profits growth, suggesting the presence of large innovation rents shared between the two, whereas medium-skilled wages have a negative impact, which is in keeping with the average impact, and, lastly, the growth of low-skilled wages has no effect on profits.

\section{References}

Acemoglu, D. (2002) Technical Change, Inequality, and the Labor Market, Journal of Economic Literature, 40(1), 7-72.

Acemoglu, D. and Autor, D. (2011) Skills, tasks and technologies: Implications for employment and earnings. In Ashenfelter, O. and Card, D. (eds.), Handbook of Labor Economics, (1 ed., Vol. 4, pp. 1043-1171). Elsevier.

Akerlof, G. A. and Yellen, J. (1990). The fair wage-effort hypothesis and unemployment. Quarterly Journal of Economics, 105(2), pp.255-283.

Amiti, M., and Wei, S. (2004) Fear of Outsourcing: Is it Justified? (No. w.186). Washington: International Monetary Fund.

Antràs, P., Garicano, L. and Rossi-Hansberg, E. (2006) Offshoring in a knowledge economy. The Quarterly Journal of Economics, 121(1), pp. 31-77.

Arai, M. (2003). Wages, profits, and capital intensity: Evidence from matched worker-firm data, Journal of Labor Economics, vol. 21, no. 3, 593-618.

Arestis, P. (1996) Post-Keynesian Economics: Towards Coherence. Cambridge Journal of Economics, 20(1), pp. 111-35.

Arpaia, A., Pérez, E. and Pichelmann, K. (2009) Understanding labour income share dynamics in Europe, MPRA Paper 15649, University Library of Munich, Germany.

Atkinson, A. B., Saez, E. and Piketty, T. (2011) Top Incomes in the Long Run of History. Journal of Economic Literature, 49(1), pp. 3-71.

Atkinson, A. B. (1999) Is Rising Income Inequality Inevitable? A Critique of the Transatlantic Consensus. Wider Annual Lecture 3.

Autor, D. H., and Handel, M., J. (2013) Putting tasks to the test: Human capital, job tasks, and wages. Journal of Labor Economics, 31. S1 (2013): S59-S96.

Bartel, A., S. Lach, and N. Sicherman (2005) Outsourcing and Technological Change. NBER Working Paper No. 11158 
Basu, D. and Vasudevan, R. (2013) Technology, distribution and the rate of profit in the US economy: understanding the current crisis. Cambridge Journal of Economics, 37(1), pp. 57-89. Oxford University Press.

Baumgarten, D., I. Geishecker, and H. Görg (2013) Offshoring, tasks, and the skill-wage pattern. European Economic Review, 61: 132-152

Becker, SO, Ekholm, K., and Muendler, MA. (2013) Offshoring and the onshore composition of tasks and skills. Journal of International Economics 90(1): 91-106

Bellemare, MF, T Masaki, TB Pepinsky (2015) Lagged Explanatory Variables and the Estimation of Causal Effects. mimeo

Bellows, J. and Miguel, E. (2009) War and local collective action in Sierra Leone. Journal of Public Economics, 93: 1144-1157.

Berman, E., Bound, J., and Griliches, Z. (1994) Changes in the demand for skilled labor within u.s. manufacturing: evidence from the annual survey of manufactures. Quarterly Journal of Economics, 109 (2), pp. 367-97.

Blinder, A. (2009) How Many U.S. Jobs Might Be Offshorable. World Economics, 10: 41-78.

Boeri, T. (2011) Reducing youth unemployment and dualism. Thematic Review Seminar on the Reduction of Labour Market Segmentation Addressing the Needs of Young People, Brussels. Vol. 27.

Bogliacino, F. (2014) Innovation and employment: A firm level analysis with European R\&D Scoreboard data. Economia, 15(2): 141-154.

Bogliacino, F. and Lucchese, M. (2015) Endogenous skill biased technical change: testing for demand pull effect. Industrial and Corporate Change, Oxford Journals, first published online April 2014, doi:10.1093/icc/dtv010

Bogliacino, F., and Maestri, V. (2014) Increasing economics inequalities? In W. Salverda, B. Nolan, D. Checchi, I. Marx, A. McKnight, and I. Tóth (Eds.). Changing Inequalities in Rich Countries: Analytical and Comparative Perspectives, pp. 15-48. Oxford University Press.

Bogliacino F. and Pianta M. (2013a) Profits, R\&D and Innovation: a Model and a Test. Industrial and Corporate Change, 22(3), pp. 649-678.

Bogliacino F. and Pianta M. (2013b) Innovation and Demand In Industry Dynamics. R\&D, New products and Profits. In A. Pyka and E.S. Andersen (Eds.). Long Term Economic Development. Berlin: Springer.

Bogliacino, F. and Pianta, M. (2016). The Pavitt Taxonomy, Revisited. Patterns of Innovation in Manufacturing and Services. Economia Politica, 33: 153-180

Booth, A. L., Francesconi, M. and Frank, J. (2002) Temporary jobs: stepping stones or dead ends? The economic journal 112.480: F189-F213. 
Bottazzi, G. and Grazzi, M. (2010) Wage-size relation and the structure of work-force composition in Italian manufacturing firms, Cambridge Journal of Economics, Volume 34, Number 4 pp. 649-669.

Bramucci, A., Cirillo, V., Evangelista, R., Guarascio, D. (2017) Offshoring, industry heterogeneity and employment. mimeo

Brunello, G. and Colussi, A. (1998) The employer size-wage effect: evidence from Italy. Labor Economics, vol. 5, pp. 217-30.

Burstein, A. and Vogel, J. (2012) International trade, technology, and the skill premium. 2012 Meeting Papers 664, Society for Economic Dynamics.

Carlin, W, A Glyn, J Van Reenen (2001) Export Market Performance of OECD Countries: An empirical Examination of The Role of Cost Competitiveness, Economic Journal, 111, 128162

Carluccio, J, A Cunat, H Fadinger and C Fons-Rosen (2015a) Offshoring and Skill-Upgrading in French Manufacturing: A Heckscher-Ohlin-Melitz View. CEPR Discussion Paper 10864.

Carluccio, J D Fougère and E Gautier (2015b) Trade, wages and collective bargaining: evidence from France. The Economic Journal, forthcoming.

Caroli, E., and Van Reenen, J. (2001) Skill-biased organizational change? Evidence from a panel of British and French establishments. The Quarterly Journal of Economics 116.4: pp. 14491492.

Castellani, D., De Benedictis, L., Horgos, D. (2013) Can we really trust offshoring indices? Structural Change and Economic Dynamics, 25: 159-172

Checchi, D. and Garcia-Penalosa, C. (2010) Labour Market Institutions and the Personal Distribution of Income in the OECD. Economica, 77(307): 413-450.

Chennells, L. and Van Reenen, J. (1999) Has technology hurt less skilled workers? An econometric survey of the effects of technical change on the structure of pay and jobs. The Institute for Fiscal Studies Working Paper Series, N. W99/27.Costinot, A. and RodriguezClare, A. (2013). Trade Theory with Numbers: Quantifying the Consequences of Globalization (No. 9398). CEPR Discussion Papers.

Cincera, M., 2005. The link between firms' R\&D by type of activity and source of funding and the decision to patent, DULBEA Working Paper 05-10.RS, Bruxelles.

Cirillo, V. (2016). Technology, employment and skills. Economics of Innovation and New Technology. Online First: 1-21

Colantone, I., Crinò, R., (2014) New imported inputs, new domestic products, Journal of International Economics, 92 (1), pp. 147-165.

Conte, A., Vivarelli, M., 2005. One or many knowledge production functions? Mapping innovative activity using microdata, IZA Discussion Paper 1878, Bonn 
Costinot, A. and Rodriguez-Clare, A (2013) Trade theory with numbers: Quantifying the consequences of globalization. No. w18896. National Bureau of Economic Research, 2013.

Crinò, R. (2009) Offshoring, multinationals and labour market: a Review of the Empirical Literature. Journal of Economic Surveys, 23(2): 197-249.

Davis, S. J. and Haltiwanger, J. (1991) Wage dispersion between and within U.S. manufacturing plants: 1963-86, Brookings Paper on Economic Activity, Microeconomics 1991, pp. 115200.

Denicoló, V. (2007). Do patents over-compensate innovators? Economic Policy, October, 679729.

Drandakis, E. and Phelps, E. (1966) A model of induced invention, growth, and distribution. Economic Journal, 76 (304), pp. 823-840.

Dosi, G. (1988) Sources, procedures and microeconomic effects of innovation. Journal of Economic Literature, vol. 26, pp.1120-1171.

Dunne, T. and Schmitz, J. A, (1995) Wages, Employment Structure and Employer Size-Wage Premia: Their Relationship to Advanced-Technology Usage at US Manufacturing Establishments, Economica, London School of Economics and Political Science, vol. 62(245), pp. 89-107, February.

Ebenstein, A., Harrison, AE, McMillan, M.S., Phillips, S (2014) Estimating the impact of trade and offshoring on American workers using the Current Population Surveys. Review of Economics and Statistics, 96(4): 581-595

Escaith, H. (2016). Revisiting growth accounting from a trade in value-added perspective. WTO Working Paper ERSD-2016-01.

European Commission (2007) Communication from the Commission to the European Parliament concerning statistics relating to external trade with nonmember countries and repealing Council Regulation (EC) No 1172/95

Falk, M. and Koebel, B. M. (2002) Outsourcing, Imports and Labour Demand, Scandinavian Journal of Economics, 104(4): 567-586

Feenstra, R. C. and Gordon, H. H. (1997) Foreign Investment and Relative Wages: Evidence from Mexico's Maquiladoras. Journal of International Economics, 42(3), pp. 371-393.

Feenstra, R.C. and Hanson, G.H. (1999) The impact of outsourcing and high-technology capital on wages: Estimates for the United States, 1979-1990. Quarterly Journal of Economics, Vol. 114, pp. 907-941.

Feenstra, R. C. and G.H. Hanson (1996). Foreign investment, outsourcing and relative wages. In R.C. Feenstra, G.M. Grossman and D.A. Irwin, (eds.). The Political Economy of Trade Policy: Papers in Honor of Jagdish Bhagwati, pp. 89-127. MIT Press.

Fellner, W. (1961) Two Propositions in the Theory of Induced Innovations. Economic Journal, 71, pp. 305-308. 
Fosse, H. and Maitra, M. (2012) Import, offshoring and wages: rent sharing or composition? Mimeo, 2012. Available at: http://openarchive.cbs.dk/bitstream/handle/10398/8540/Fosse_2012_2.pdf?sequence=1

Foster-McGregor N., Pöschl, J. and Stehrer, R. (2016) Offshoring and the Elasticity of Labour Demand, Open Economies Review, Springer, vol. 27(3), pp. 515-540, July.

Geishecker, I. and Görg, H. (2008) Winners and losers: A micro-level analysis of international outsourcing and wages. Canadian Journal of Economics, 41 (1), pp. 243-270.

Gonzales, F. and Miguel, E. (2015) War and local collective action in Sierra Leone: A comment on the use of coefficient stability approaches. Journal of Public Economics, 128: 30-33.

Goos, M., A. Manning, and A Salomons (2014) Explaining Job Polarization: Routine-Biased Technological Change and Offshoring. American Economic Review, 104(8): 2509-2526

Görg, H., and Görlich, D. (2015) Offshoring, wages and job security of temporary workers. Review of World Economics 151.3: 533-554.

Görg, H. and Hanley, A. (2011) Services outsourcing and innovation: an empirical investigation. Economic Inquiry, Western Economic Association International, 49(2), pp. 321-333.

Grossman, G. and Rossi-Hansberg, E. (2007) The Rise of Offshoring: It's Not Wine for Cloth Anymore' In The New Economic Geography: Effects and Policy Implications, 59-102. A Symposium Sponsored by the Federal Reserve Bank of Kansas City. Jackson Hole, Wyoming.

Grossman, G. and Rossi-Hansberg, E. (2008) Trading Tasks: A Simple Theory of Offshoring. American Economic Review 98 (5): 1978-97.

Guarascio, D., Pianta, M. and Bogliacino, F. (2014) Export, R\&D and new products: A model and a test on European industries, Journal of evolutionary economics.

Guarascio, D., Pianta, M., Lucchese, M. and Bogliacino, F. (2015) Business cycles, technology and exports. Economia Politica - Journal of Analytical and Institutional Economics, 32(2), pp. 167-200.

Harrison, A., and McMillan, M (2011) Offshoring jobs? Multinationals and US manufacturing employment. Review of Economics and Statistics, 93.3 (2011): 857-875.

Helg, R. and L. Tajoli (2005) Patterns of international fragmentation of production and the relative demand for labor, The North American Journal of Economics and Finance, 16(2):233-254

Hicks, J. R. (1932) The theory of wages. MacMillan London.

Hijzen, A., Tomohiko I. and Yasuyuki T. (2010) Does offshoring pay? Firm-level evidence from Japan. Economic Inquiry, 48(4), pp. 880-895.

Horgos, D. (2009) Labor market effects of international outsourcing: How measurement matters. International Review of Economics and Finance, 18: 611-623.

Horgos, D and L. Tajoli (2015) How Offshoring Can Affect the Industries' Skill Composition. Economies 2015, 3, 72-99 
Howell, D. R. (1999) Theory-Driven Facts and the Growth in Earnings Inequality. Review of Radical Political Economics, 31, pp. 54-86.

Hummels, D., Jorgensen, J., Munch, R. and Xiang, C. (2014) The Wage Effects of Offshoring: Evidence from Danish Matched Worker-Firm Data. American Economic Review, 104(6), pp. 1597-1629.

International Labor Organization (2015) Global wage report: wages and income inequality. International Labour Organization.

Jorgenson, D. W. and Timmer, M. P. (2011) Structural Change in Advanced Nations: A New Set of Stylised Facts. Scandinavian Journal of Economics, 113(1): 1-29.

Kalecki, M. (1939) Essays in the theory of economic fluctuations. In Osiatynski, J. (2007). Collected works of M. Kalecki. Vol. I: Capitalism, business and full employment. Clarendon Press Oxford.

Kennedy, C. (1964) Induced bias in innovation and the theory of distribution. Economic Journal, 74 (295), pp. 541-547.

Kahn, L. M. (2007). The impact of employment protection mandates on demographic temporary employment patterns: International microeconomic evidence. The Economic Journal, 117(521), F333-F356.

Kramarz, F. (2008) Offshoring, wages and employment: evidence form data matching imports, firms and workers. CREST-INSEE mimeo Available at: http://www.crest.fr/ckfinder/userfiles/files/pageperso/kramarz/offshoring072008.pdf

Lallemand, T., Plasman, R. and Rycx, F. (2005) 'The Establishment-size Wage Premium: Evidence from European Countries', IZA Discussion Papers 1569, Institute for the Study of Labor (IZA).

Landesmann, M. Leitner, S. and Stehrer, R. (2015) Competitiveness of the European economy wiiw Research Report No. 401, May 2015.

Lee, H., and Lee, J. (2015) The impact of offshoring on temporary workers: evidence on wages from South Korea. Review of World Economics 151.3: pp. 555-587.

Lewbel, A. (2012) Using Heteroscedasticity to Identify and Estimate Mismeasured and Endogenous Regressor Models. Journal of Business \& Economic Statistics, Taylor \& Francis Journals, vol. 30(1), pp. 67-80, December.

Lewin, A. Y., Massini, S., Peeters, C. (2009). Why Are Companies Offshoring Innovation? The Emerging Global Race for Talent, Journal of International Business Studies, 40(6): 901925.

Lucchese, M. and Pianta, M. (2012) Innovation and Employment in Economic Cycles. Comparative Economic Studies, 54(2), pp. 341-359, June. Palgrave Macmillan.

Malerba, F. (ed.) (2004) Sectoral systems of innovation. Cambridge: Cambridge University Press. 
Main, B. G. M. and Reilly, B. (1993) The employer size-wage gap: evidence from Britain, Economica, vol. 60, pp. 125-42.

Marx, K. (1867) Capital, Vol. I. The Process of Capitalist Production. Frederick Engels, Ernest Untermann, eds. Samuel Moore, Edward Aveling, trans. 1906. Library of Economics and Liberty. 30 March 2015.

Milberg, W. and Winkler, D. (2010) Financialisation and the dynamics of offshoring in the USA. Cambridge Journal of Economics, 34(2), pp. 275-293, March. Oxford University Press.

Milberg, W. and Winkler, D. (2013) Outsourcing economics: Global value chains in capitalist development. Cambridge University Press.

Millimet, D.L., and Roy, J. (2015) Empirical tests of the pollution haven hypothesis when environmental regulation is endogenous. Journal of Applied Econometrics, Vol. 31, Issue 4, June/July 2016, pp. 652-677.

Mion, G and L Zhu (2013) Import competition from and offshoring to China: A curse or blessing for firms? Journal of International Economics, 89(1), pp. 202-215.

Morrison Paul, C. J. and Siegel, D. S. (2001) The Impacts of Technology, Trade and Outsourcing on Employment and Labor Composition. Scandinavian Journal of Economics, 103(2), 241264.

Munch, J. R. (2010) Whose Job Goes Abroad? International Outsourcing and Individual Job Separations. Scandinavian Journal of Economics, 112(2): 339-360.

Newfarmer, R., M. Sztajerowska (2012) Trade and Employment in a Fast-Changing World, in: Lippoldt, D. (Ed.) Policy Priorities for International Trade and Jobs. OECD, Chapter: 1, 7 73

OECD, (2011) Divided We Stand: Why Inequality Keeps Rising. OECD Publishing.

OECD, (2008) Growing Unequal? Income Distribution and Poverty in OECD Countries. OECD Publishing.

Oldenski L. (2014), Offshoring and the polarization of US labor market, Industrial and Labor Relations Review, 67: 734-761

Oster, E. (2015) Unobservable Selection and Coefficient Stability: Theory and Evidence. mimeo

Parisi, M.L., Schiantarelli, F., Sembenelli, A., (2006) Productivity, innovation and R\&D: micro evidence for Italy. European Economic Review 50, 2037-2061

Perani, C. and Cirillo, V. (2015) Matching industry classifications. A method for converting Nace Rev.2 to Nace Rev.1 (No. 1502). University of Urbino Carlo Bo, Department of Economics, Society \& Politics - revised 2015.

Pianta, M., Tancioni, M. (2008) Innovations, profits and wages. Journal of Post Keynesian Economics, 31(1), pp. 103-123.

Piketty, T. (2014) Capital in the twenty-first century. Cambridge: Harvard University Press. 
Piva, M., Santarelli, E. and Vivarelli, M. (2005) The skill bias effect of technological and organisational change: Evidence and policy implications. Research Policy 34.2 (2005): 141-157.

Reed, W R (2014), A Note on the Practice of Lagging Variables to Avoid Simultaneity, Oxford Bulletin of Economics and Statistics, 77(6): 897-905

Ricardo, D. (1815) An Essay on the Effects of a Low Price of Corn on the Profits of Stock etc. In P. Sraffa, (ed.). Works and Correspondence of David Ricardo, 4. Cambridge: Cambridge University Press, 1951.

Salter, E. W. G. (1960) Productivity and technical change. Cambridge University Press. Cambridge, Mass, 1(6), 0.

Samuelson, P. A. (1965) A theory of induced innovations along Kennedy-Weisacker lines. Review of Economics and Statistics, 47, pp. 343-356.

Schlenker, E. and Schmid D. (2013) Capital Income Shares and Income Inequality in the European Union (IMK Working Paper 119). IMK at the Hans Boeckler Foundation, Macroeconomic Policy Institute.

Schmookler, J. (1966) Inventions and Economic Growth. Harvard University Press: Cambridge.

Schumpeter, J.A. (1975) Capitalism, Socialism and Democracy. New York: Harper (1st edn 1942).

Shapiro, C. and Stiglitz, J. (1984) Equilibrium unemployment as a worker discipline device. The American Economic Review, 74(3), pp. 433-444.

Sheng, L. and Yang, D. T. (2012) The Ownership Structure of Offshoring and Wage Inequality: Theory and Evidence from China, mimeo. Available at: https://www.econ.cuhk.edu.hk/dept/seminar/12-13/1st-term/shengyang2012.pdf

Slaughter, M. J. (2000) Production transfer within multinational enterprises and American wages. Journal of International Economics, 50(2), pp. 449-72.

Stapel, S., J. Pasanen, and S. Reinecke (2004) Purchasing Power Parities and related economic indicators for EU, Candidate Countries and EFTA. Eurostat - Statistics in Focus.

Stockhammer, E. (2013) Why have wage shares fallen? A panel analysis of the determinants of functional income distribution (conditions of work and employment $\mathrm{N}^{\circ} 35$ ): for the International Labour Organisation (ILO) project" New Perspectives on Wages and Economic Growth" (No. 470913). International Labour Organization.

Stiglitz, J. (2012) The price of inequality: how today's divided society endangers our future. New York: W.W. Norton and Company editions.

Timmer, M., Los, B., Stehrer, R. and de Vries, G. (2013) Fragmentation, incomes and jobs: An analysis of European competitiveness. Economic Policy, 28 (76) pp.613-661. 
Van der Hoeven, R. (2014) Profits without labour benefits. The impact of financial globalization on work. Available at: http://www.thebrokeronline.eu/Articles/Profits-without-labourbenefits

Van Reenen, J. (1996) The creation and capture of rents: wages and innovation in a panel of UK companies. The Quarterly Journal of Economics, 111(1), pp. 195-226, February. MIT Press.

Von Weizsäcker, C. (1966) Tentative notes on a two-sector model with induced technical progress. Review of Economic Studies, 33 (3), pp. 245-52.

Wooldridge, J. M. (2002), Econometric Analysis of Cross Section and Panel Data. MIT Press: Cambridge.

Yamano, N., Ahmad, N. (2006) The OECD Input-Output Database: 2006 Edition, OECD Science, Technology and Industry Working Papers 2006/8. OECD Publishing.

Zamparelli, L. (2011) Induced Innovation, Endogenous Growth, and Income Distribution: a Model along Classical Lines (No. 1102). Dipartimento di Economia e Finanza, LUISS Guido Carli. 


\section{Appendix}

Figure A1. The average rate of change of wages and profits in the four subperiods.

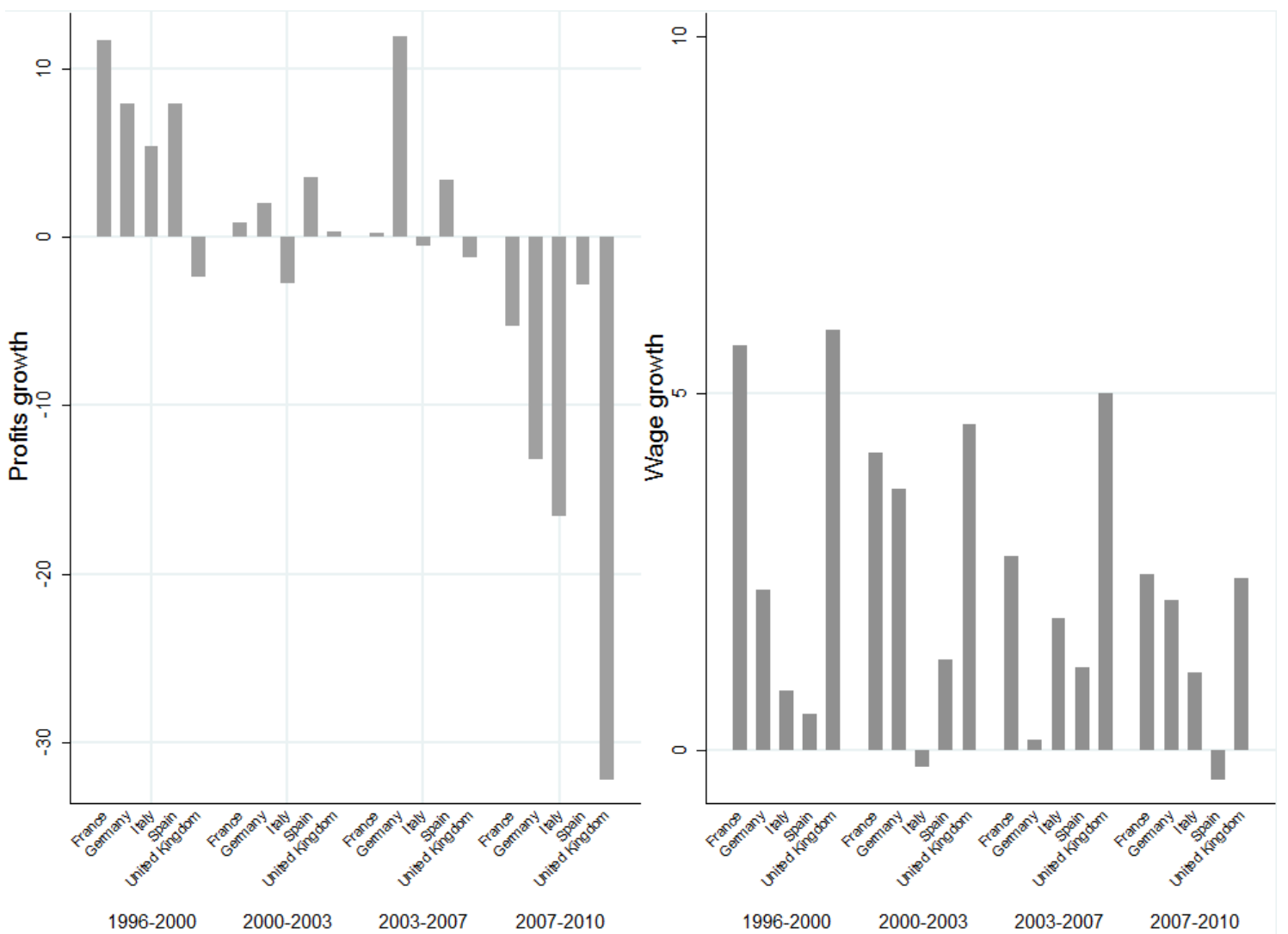

Source: SID database. Compound average rate of change of wages per worked hour and Compound average rate of change of total sectoral gross operating surplus. 
Table A1. The Wages WLS estimation using different innovation variables Dependent Variable: Compound average rate of change of wages per worked hour.

WLS with White-Huber robust standard errors and weighted data (weights are the numbers of employee in the sector) Robust standard errors in brackets: ${ }^{*} \mathrm{p}<.10,{ }^{* *} \mathrm{p}<.05,{ }^{* * *} \mathrm{p}<.01$.

\begin{tabular}{|c|c|c|c|c|}
\hline & $\begin{array}{l}\text { (1) } \\
\text { WLS model }\end{array}$ & $\begin{array}{l}\text { (2) } \\
\text { WLS model }\end{array}$ & $\begin{array}{l}\text { (3) } \\
\text { WLS model }\end{array}$ & $\begin{array}{l}\text { (4) } \\
\text { WLS model }\end{array}$ \\
\hline $\begin{array}{l}\text { Share of innovative firms (first } \\
\text { lag) }\end{array}$ & $\begin{array}{l}0.08 \\
{[0.01]^{* * * *}}\end{array}$ & & & \\
\hline $\begin{array}{l}\text { Share of innovative firms - } \\
\text { squared (first lag) }\end{array}$ & $\begin{array}{l}-0.00 \\
{[0.00]^{* *}}\end{array}$ & & & \\
\hline $\begin{array}{l}\text { Share of product innovators (first } \\
\text { lag) }\end{array}$ & & $\begin{array}{l}0.05 \\
{[0.01]^{* * *}}\end{array}$ & & \\
\hline $\begin{array}{l}\text { Share of product innovators - } \\
\text { squared (first lag) }\end{array}$ & & $\begin{array}{l}-0.00 \\
{[0.00]}\end{array}$ & & \\
\hline $\begin{array}{l}\text { Share of firms introducing } \\
\text { products new to the market (first } \\
\text { lag) }\end{array}$ & & & $\begin{array}{l}0.08 \\
{[0.01]^{* * *}}\end{array}$ & \\
\hline $\begin{array}{l}\text { Share of firms introducing } \\
\text { products new to the market - } \\
\text { squared (first lag) }\end{array}$ & & & $\begin{array}{l}-0.00 \\
{[0.00]}\end{array}$ & \\
\hline $\begin{array}{l}\text { Share of innovators relying on } \\
\text { internal resources (first lag) }\end{array}$ & & & & $\begin{array}{l}0.08 \\
{[0.01]^{* * *}}\end{array}$ \\
\hline $\begin{array}{l}\text { Share of innovators relying on } \\
\text { internal resources - squared (first } \\
\text { lag) }\end{array}$ & & & & $\begin{array}{l}-0.00 \\
{[0.00]^{* * *}}\end{array}$ \\
\hline Offshoring (first lag) & $\begin{array}{l}-0.02 \\
{[0.30]}\end{array}$ & $\begin{array}{l}0.16 \\
{[0.38]}\end{array}$ & $\begin{array}{l}-0.17 \\
{[0.25]}\end{array}$ & $\begin{array}{l}-0.26 \\
{[0.27]}\end{array}$ \\
\hline Offshoring squared (first lag) & $\begin{array}{l}2.96 \\
{[3.87]}\end{array}$ & $\begin{array}{l}3.61 \\
{[3.68]}\end{array}$ & $\begin{array}{l}3.95 \\
{[3.89]}\end{array}$ & $\begin{array}{l}4.67 \\
{[3.57]}\end{array}$ \\
\hline $\begin{array}{l}\text { Techn. Change* Offshoring (first } \\
\text { lag) }\end{array}$ & $\begin{array}{l}-0.00 \\
{[0.00]}\end{array}$ & $\begin{array}{l}-0.00 \\
{[0.00]}\end{array}$ & $\begin{array}{l}-0.00 \\
{[0.00]}\end{array}$ & $\begin{array}{l}-0.00 \\
{[0.00]}\end{array}$ \\
\hline$\Delta$ Employment (first lag) & $\begin{array}{l}0.00 \\
{[0.03]}\end{array}$ & $\begin{array}{l}-0.00 \\
{[0.03]}\end{array}$ & $\begin{array}{l}0.00 \\
{[0.03]}\end{array}$ & $\begin{array}{l}0.00 \\
{[0.03]}\end{array}$ \\
\hline$\Delta$ Gross Output (first lag) & $\begin{array}{l}0.06 \\
{[0.03]^{*}}\end{array}$ & $\begin{array}{l}0.07 \\
{[0.03]^{* *}}\end{array}$ & $\begin{array}{l}0.06 \\
{[0.03]^{*}}\end{array}$ & $\begin{array}{l}0.06 \\
{[0.03]^{*}}\end{array}$ \\
\hline N.observations & 433 & 492 & 467 & 467 \\
\hline R2 (Adj) & 0.29 & 0.28 & 0.32 & 0.30 \\
\hline
\end{tabular}


Table A2. The Wages WLS estimation controlling for human capital Dependent Variable: Compound average rate of change of wages per worked hour.

WLS with White-Huber robust standard errors and weighted data (weights are the numbers of employee in the sector) Robust standard errors in brackets: ${ }^{*} \mathrm{p}<.10,{ }^{* *} \mathrm{p}<.05,{ }^{* * *} \mathrm{p}<.01$.

\begin{tabular}{lll}
\hline & $(\mathbf{1})$ & $\mathbf{( 2 )}$ \\
& WLS model & WLS model \\
\hline R\&D expenditure (first lag) & 0.35 & 0.39 \\
& {$[0.11]^{* * *}$} & {$[0.10]^{* * *}$} \\
R\&D expenditure squared (first & -0.00 & -0.00 \\
lag) & {$[0.00]^{*}$} & {$[0.00]^{* *}$} \\
Offshoring (first lag) & -0.25 & -0.23 \\
& {$[0.15]^{*}$} & {$[0.14]$} \\
Offshoring squared (first lag) & 2.37 & 2.73 \\
& {$[2.91]$} & {$[2.75]$} \\
R\&D*Offshoring (first lag) & -0.02 & -0.02 \\
& {$[0.01]$} & {$[0.02]$} \\
$\Delta$ Employment (first lag) & 0.02 & 0.02 \\
& {$[0.04]$} & {$[0.04]$} \\
$\Delta$ Gross Output (first lag) & 0.04 & 0.06 \\
& {$[0.03]$} & {$[0.04]^{*}$} \\
Share of workers with tertiary & -0.3 & \\
educ. & {$[0.01]^{*}$} & \\
Share of workers with secondary & 0.02 & \\
educ. & {$[0.01]^{*}$} & -0.00 \\
Share of managers & & {$[0.01]$} \\
Share of clerks & & -0.01 \\
& & {$[0.01]$} \\
N.observations & & 413 \\
R2 (Adj) & 413 & 0.35 \\
\hline
\end{tabular}


Table A3. The profits equation

Dependent Variable: Compound average rate of change of total sectoral gross operating surplus

WLS with White-Huber robust standard errors and weighted data (weights are the numbers of employee in the sector), IV (endogenous regressors: compound rate of change of domestic demand and compound rate of change of exports; instruments: first lag of the endogenous regressors, lagged sectoral value added, country, time and Pavitt dummies), Robust standard errors in brackets: ${ }^{*} \mathrm{p}<.10,{ }^{* *} \mathrm{p}<.05,{ }^{* * *} \mathrm{p}<.01$.

\begin{tabular}{lll}
\hline & $(\mathbf{1})$ & $\mathbf{( 2 )}$ \\
& WLS model & $\mathbf{I V}$ \\
\hline$\Delta$ Wages/worked hour & -1.44 & -1.43 \\
& {$[0.20]^{* * *}$} & {$[0.34]^{* * *}$} \\
Average firm size & -0.37 & -0.25 \\
& {$[0.31]$} & {$[0.65]$} \\
New mach. per employee (first lag) & 0.30 & 0.30 \\
& {$[0.48]$} & {$[0.61]$} \\
$\Delta$ Domestic demand & 0.35 & 0.62 \\
& {$[0.12]^{* * *}$} & {$[0.30]$} \\
$\Delta$ Exports & 0.10 & 1.05 \\
Share of managers & {$[0.07]$} & {$[0.0 .28]^{* * *}$} \\
Share of clerks & 0.02 & -0.039 \\
& {$[0.07]$} & {$[0.06]$} \\
N.observations & -0.12 & -0.03 \\
R2 (Adj) & {$[0.17]$} & {$[0.09]$} \\
\hline
\end{tabular}


Table A4. The profits equation: test on omitted variable bias

Source: The Table refers to the impact of wages (panel A), domestic demand (B), and export (C) in the profits equation. alfa ${ }^{*}$ and $\mathrm{R}^{*}$ are the coefficient estimate and $\mathrm{R}$ squared from the regression using observable covariates, and alfa ${ }^{\circ}$ and $\mathrm{R}^{\mathrm{o}}$ are the coefficient and $\mathrm{R}$ squared from the uncontrolled regression. Rmax is the $\mathrm{R}$ squared of a regression of the outcome variables over observables and unobservables. In C Rmax=1 (zero measurement error); in $B M, R m a x=2 R^{*}$ $\mathrm{R}^{\mathrm{o}}$ (Bellows and Miguel, 2009); in O, Rmax=Min $\left\{2.2 \mathrm{R}^{*}, 1\right\}$ (Oster, 2015), and, finally, in $\mathrm{R}, \mathrm{Rmax}=.8$ (measurement error equal to 20\%). Alfa corrected is the estimated coefficient after the correction for the bias (see equation 11 in section 3.3).

\begin{tabular}{|c|c|c|c|c|}
\hline (A) Wage & $\overline{\mathbf{B M}}$ & $\overline{\mathrm{OS}}$ & $\bar{C}$ & $\mathbf{R}$ \\
\hline alfa* & -1.23 & -1.23 & -1.23 & -1.23 \\
\hline alfa $^{0}$ & -0.71 & -0.71 & -0.71 & -0.71 \\
\hline $\mathbf{R}^{*}$ & 0.174 & 0.174 & 0.174 & 0.174 \\
\hline $\mathbf{R}^{\mathbf{o}}$ & 0.02 & 0.02 & 0.02 & 0.02 \\
\hline $\operatorname{Rmax}$ & 0.328 & 0.3828 & 1 & 0.8 \\
\hline alfa corrected & -1.75 & -1.94 & -4.01 & -3.34 \\
\hline $\begin{array}{l}\text { (B) Domestic } \\
\text { demand }\end{array}$ & $\mathrm{BM}$ & OS & $\mathrm{C}$ & $\mathrm{R}$ \\
\hline alfa* & 0.26 & 0.26 & 0.26 & 0.26 \\
\hline alfa $^{\circ}$ & 0.38 & 0.38 & 0.38 & 0.38 \\
\hline $\mathbf{R}^{*}$ & 0.174 & 0.174 & 0.174 & 0.174 \\
\hline $\mathbf{R}^{\mathbf{o}}$ & 0.041 & 0.041 & 0.041 & 0.041 \\
\hline $\operatorname{Rmax}$ & 0.307 & 0.3828 & 1 & 0.8 \\
\hline alfa corrected & 0,14 & 0,07 & $-0,49$ & $-0,30$ \\
\hline (C) Export & BM & OS & $\mathrm{C}$ & $\mathrm{R}$ \\
\hline alfa* & 0.13 & 0.13 & 0.13 & 0.13 \\
\hline alfa $^{\circ}$ & 0.04 & 0.04 & 0.04 & 0.04 \\
\hline $\mathbf{R}^{*}$ & 0.174 & 0.174 & 0.174 & 0.174 \\
\hline $\mathbf{R}^{\mathbf{o}}$ & 0.004 & 0.004 & 0.004 & 0.004 \\
\hline $\operatorname{Rmax}$ & 0.328 & 0.3828 & 1 & 0.8 \\
\hline alfa corrected & 0,22 & 0,24 & 0,57 & 0,46 \\
\hline
\end{tabular}

